\title{
Primary production and carbon export rates across the subpolar $N$. Atlantic Ocean basin based on triple oxygen isotope and dissolved $\mathrm{O}_{2}$ and Ar gas measurements
}

\author{
P. Quay, ${ }^{1}$ J. Stutsman, ${ }^{1}$ and T. Steinhoff ${ }^{2}$ \\ Received 24 November 2010; revised 18 January 2012; accepted 13 February 2012; published 17 April 2012.
}

[1] Gross photosynthetic $\mathrm{O}_{2}$ production (GOP) rates in the subpolar North Atlantic Ocean were estimated using the measured isotopic composition of dissolved oxygen in the surface layer on samples collected on nine transits of a container ship between Great Britain and Canada during March 2007 to June 2008. The mean basin-wide GOP rate of $226 \pm 48 \mathrm{mmol} \mathrm{O}_{2} \mathrm{~m}^{-2} \mathrm{~d}^{-1}$ during summer was double the winter rate of $107 \pm 41 \mathrm{mmol} \mathrm{O}_{2} \mathrm{~m}^{-2} \mathrm{~d}^{-1}$. Converting these GOP rates to equivalent ${ }^{14} \mathrm{C}$-based PP $\left({ }^{14} \mathrm{C}-\mathrm{PP}\right.$ eqv $)$ yielded rates of $1005 \pm 216$ and $476 \pm 183 \mathrm{mg} \mathrm{C} \mathrm{m}^{-2} \mathrm{~d}^{-1}$ in summer and winter, respectively, that generally agreed well with previous ${ }^{14} \mathrm{C}$-based PP estimates in the region. The ${ }^{14} \mathrm{C}-\mathrm{PP}_{\text {eqv }}$ estimates were $1-1.6 \times$ concurrent satellite-based $\mathrm{PP}$ estimates along the cruise track. A net community production rate (NCP) of $87 \pm 12 \mathrm{mmol} \mathrm{O}_{2} \mathrm{~m}^{-2} \mathrm{~d}^{-1}$ $\left(62 \pm 9 \mathrm{mmol} \mathrm{C} \mathrm{m}^{-2} \mathrm{~d}^{-1}\right)$ and NCP/GOP of $0.35 \pm 0.06$ in the mixed layer was estimated from $\mathrm{O}_{2} / \mathrm{Ar}$ and ${ }^{17} \Delta$ measurements $\left(61^{\circ} \mathrm{N} 26^{\circ} \mathrm{W}\right)$ during spring bloom conditions in May 2008. Contrastingly, a much lower long-term annual mean NCP or organic carbon export rate of $2.8 \pm 2.7 \mathrm{~mol} \mathrm{C} \mathrm{m}^{-2} \mathrm{yr}^{-1}\left(8 \pm 7 \mathrm{mmol} \mathrm{C} \mathrm{m}^{-2} \mathrm{~d}^{-1}\right)$ and NCP/GOP of $0.07 \pm 0.06$ at the winter mixed layer depth was estimated from 15 years of surface $\mathrm{O}_{2}$ data in the subpolar N. Atlantic collected during the CARINA program.

Citation: Quay, P., J. Stutsman, and T. Steinhoff (2012), Primary production and carbon export rates across the subpolar $\mathrm{N}$. Atlantic Ocean basin based on triple oxygen isotope and dissolved $\mathrm{O}_{2}$ and Ar gas measurements, Global Biogeochem. Cycles, 26, GB2003, doi:10.1029/2010GB004003.

\section{Introduction}

[2] The rate of photosynthetic production of organic carbon is the foundation of ocean's food web and biological carbon pump. Yet for many regions of the ocean the spatial and temporal variability of primary production (PP) rates is poorly known because there have been only sporadic snapshot measurements of PP. Although satellite-based estimates of PP potentially yield wide spatial and weekly temporal resolution, there is a factor of two range in PP estimates for algorithms using satellite data that underscores the need for validation with observations [Campbell et al., 2002].

[3] The introduction of non-incubation based PP methods, for example based on fluorometry [Kolber et al., 1998] and oxygen isotopes [Luz and Barkan, 2000], provide the opportunity to substantially improve our understanding on PP variability in the ocean. Over the last few years the oxygen isotope based method that estimates gross photosynthetic oxygen production (referred to here as ${ }^{17} \Delta$-GOP) has been applied in several regions of the ocean, i.e.,

\footnotetext{
${ }^{1}$ School of Oceanography, University of Washington, Seattle, Washington, USA.

${ }^{2}$ IFM-GEOMAR, Leibniz Institut für Meereswissenschaften, Kiel, Germany.

Copyright 2012 by the American Geophysical Union. 0886-6236/12/2010GB004003
}

subtropical N. Atlantic and N. Pacific, Southern Ocean, equatorial Pacific and coastal ocean. Key advantages of the ${ }^{17} \Delta$-GOP method are its integration time (weeks) and independence from bottle incubations, which not only avoids the methodological issues inherent with an incubation PP method [e.g., Peterson, 1980; Marra, 2009], but potentially yields a GOP estimate wherever a surface seawater sample can be collected and the air-sea $\mathrm{O}_{2}$ gas exchange rate can be estimated. Thus the ${ }^{17} \Delta$-GOP method potentially can yield much greater spatial and temporal coverage of PP in the ocean. For example, the ${ }^{17} \Delta$-GOP method applied to surface water samples collected while underway using a container ship provided multiple basin-wide snapshots of PP rates across the subtropical and equatorial Pacific [Juranek and Quay, 2010] that would have been impossible to accomplish with the traditional ${ }^{14} \mathrm{C}$ incubation PP method $\left({ }^{14} \mathrm{C}-\mathrm{PP}\right)$.

[4] From the perspective of the ocean's carbon cycle, the most important biological production rate is net community production (NCP), which equals the difference between gross $\mathrm{PP}$ and community respiration $(\mathrm{R})$. NCP, at steady state, represents the organic carbon (OC) in both dissolved and particulate phases that is available for export or harvest. NCP has been estimated by several methods (e.g., budgets for dissolved oxygen, dissolved inorganic carbon (DIC), nutrients and Thorium-234, sediment traps, $\mathrm{O}_{2}$ and ${ }^{15} \mathrm{NO}_{3}$ incubations, etc.). However, each approach has substantial 
Table 1. Estimates of Primary Production in mmol $\mathrm{C} \mathrm{m}^{-2} \mathrm{~d}^{-1}$ Based on ${ }^{14} \mathrm{C}$ Incubation Method in the Subpolar North Atlantic ${ }^{\mathrm{a}}$

\begin{tabular}{|c|c|c|c|}
\hline Site & Rate $^{\mathrm{b}}$ & Time Interval & Reference \\
\hline \multirow[t]{3}{*}{ JGOFS/NABE $\left(49^{\circ} \mathrm{N} 17^{\circ} \mathrm{W}\right)$} & $90 \pm 13(1080 \pm 153)$ & May 1989 & Martin et al. [1993] \\
\hline & $70 \pm 30(840 \pm 350)$ & May 1990 & Bury et al. [2001] \\
\hline & $105 \pm 17^{\mathrm{c}}(1260 \pm 198)$ & Apr-May 1989 & Bender et al. [1992] \\
\hline \multirow[t]{3}{*}{ JGOFS/NABE $\left(47^{\circ}-60^{\circ} \mathrm{N}, 20^{\circ} \mathrm{W}\right)$} & $48 \pm 12(580 \pm 140)$ & May 1990 & Joint et al. [1993] \\
\hline & $53 \pm 11(639 \pm 124)$ & Jun 1990 & Joint et al. [1993] \\
\hline & $36 \pm 3(425 \pm 33)$ & Jul 1990 & Joint et al. [1993] \\
\hline \multirow[t]{3}{*}{$\mathrm{POMME}^{\mathrm{c}, \mathrm{d}}\left(38^{\circ}-45^{\circ} \mathrm{N}, 16^{\circ}-22^{\circ} \mathrm{W}\right)$} & $38 \pm 7(456 \pm 81)$ & Jan-Feb 2001 & Fernandez et al. [2005] \\
\hline & $103 \pm 17(1236 \pm 202)$ & Mar-Apr 2001 & Fernandez et al. [2005] \\
\hline & $35 \pm 4(420 \pm 51)$ & Aug-Sep 2001 & Fernandez et al. [2005] \\
\hline \multirow[t]{3}{*}{ Gulf of Maine and Georges Bank $\left(40^{\circ}-42^{\circ} \mathrm{N}, 68^{\circ}-73^{\circ} \mathrm{W}\right)$} & $101 \pm 15(1211 \pm 184)$ & Summer & MARMAP $1978-1982$ \\
\hline & $31 \pm 9(371 \pm 105)$ & Winter & \\
\hline & $75 \pm 14(902 \pm 163)$ & Annual & \\
\hline \multirow[t]{3}{*}{ Subpolar N. Atlantic $\left(45^{\circ}-55^{\circ} \mathrm{N} 10^{\circ}-60^{\circ} \mathrm{W}\right)$} & $84 \pm 18^{\mathrm{e}}(1005 \pm 216)$ & May-Sep 2007-08 & This study \\
\hline & $40 \pm 15^{\mathrm{e}}(476 \pm 183)$ & Nov-Mar 2007-08 & This study \\
\hline & $62 \pm 17^{\mathrm{e}}(740 \pm 200)$ & Annual 2007-08 & This study \\
\hline
\end{tabular}

${ }^{\mathrm{a}}$ Values in parentheses are measured in $\mathrm{mg} \mathrm{C} \mathrm{m}{ }^{-2} \mathrm{~d}^{-1}$.

${ }^{b}$ Uncertainties represent standard error in mean at $95 \%$ confidence level $\left(2 \mathrm{SD} / \mathrm{V}_{\mathrm{n}}\right)$.

${ }^{\mathrm{c}}$ Dawn to dusk incubation.

${ }^{\mathrm{d}}$ Uses ${ }^{13} \mathrm{C}$ for labeling rather than ${ }^{14} \mathrm{C}$ and on-board incubations rather than in-situ.

${ }^{\mathrm{e}}$ Equivalent ${ }^{14} \mathrm{C}$-PP which equals ${ }^{17} \Delta$-GOP/2.7, as discussed in text.

uncertainty and potential biases. Only at a few sites have multiple NCP methods been compared systematically (e.g., JGOFS study sites, BATS and HOT time series sites). Thus, for most of the ocean the spatial and temporal variability of NCP is poorly constrained. The lack of NCP estimates and biases between methods may be responsible for reports of net ecosystem heterotrophy in the oligotrophic ocean surface layer based on bottle $\mathrm{O}_{2}$ incubations [e.g., Williams et al., 2004] that contradict reports of net ecosystem autotrophy based on mixed layer $\mathrm{O}_{2}$ and Ar budgets at the same location [e.g., Emerson et al., 1997; Quay et al., 2010].

[5] Here we present the results of nine snapshots of gross oxygen production rates across the subpolar N. Atlantic Ocean based on the ${ }^{17} \Delta$-GOP method using water samples collected during container ship crossings between Liverpool, GB and Halifax, Canada in 2007-2008. Additionally, we present ${ }^{17} \Delta$-GOP and NCP rates using samples collected during a research cruise in the Iceland Basin $\left(61^{\circ} \mathrm{N} 26^{\circ} \mathrm{W}\right)$ under spring bloom conditions in May 2008. We find a strong seasonality in ${ }^{17} \Delta$-GOP with summer rates at $226 \pm$ $48 \mathrm{mmol} \mathrm{O}_{2} \mathrm{~m}^{-2} \mathrm{~d}^{-1}$ being double winter rates of $107 \pm 41$ mmol O $\mathrm{m}^{-2} \mathrm{~d}^{-1}$. We estimate the equivalent ${ }^{14} \mathrm{C}$-PP rates based on ${ }^{17} \Delta$-GOP and compare these rates to historic ${ }^{14} \mathrm{C}$ PP measurements and PP rates estimated from two satellitebased algorithms. We estimate an NCP rate of $87 \pm$ $12 \mathrm{mmol} \mathrm{O}_{2} \mathrm{~m}^{-2} \mathrm{~d}^{-1}\left(62 \pm 9 \mathrm{mmol} \mathrm{C} \mathrm{m} \mathrm{C}^{-2} \mathrm{~d}^{-1}\right)$ and an export ratio (NCP/GOP) of $0.35 \pm 0.06$ based on the measured dissolved $\mathrm{O}_{2} / \mathrm{Ar}$ gas ratio in May 2008. In contrast, much lower annual NCP of $11 \pm 10 \mathrm{mmol} \mathrm{O}_{2} \mathrm{~m}^{-2} \mathrm{~d}^{-1}$ and $\mathrm{NCP} / \mathrm{GOP}$ of $0.07 \pm 0.06$ were estimated from basinwide surface $\mathrm{O}_{2}$ measurements in the region during the CARINA program between 1991 and 2005.

\section{Background}

[6] Two aspects of the ocean's carbon cycle that stand out in the subpolar N. Atlantic $\left(45^{\circ}-65^{\circ} \mathrm{N}\right)$ are the occurrence of the spring bloom [e.g., Sverdrup, 1953; Siegel et al., 2002] and the high burden of anthropogenic $\mathrm{CO}_{2}$ that has accumulated in the region at $\sim 3 \times$ the global average [Sabine et al., 2004]. Draw down of $\mathrm{CO}_{2}$ by phytoplankton productivity, coupled with seasonal cooling of surface waters, are the major factors yielding high rates of atmospheric $\mathrm{CO}_{2}$ uptake in the N. Atlantic [e.g., Takahashi et al., 2009]. Both these processes will likely be affected by global warming, as demonstrated by the study of Cermeno et al. [2008] who established a possible link between global warming, stratification, ecosystem structure, biological productivity and $\mathrm{CO}_{2}$ uptake. Thus, future rates of $\mathrm{PP}$ and atmospheric $\mathrm{CO}_{2}$ uptake in the subpolar N. Atlantic are likely to change.

[7] The link between physical forcing and biological response in the subpolar N. Atlantic is a source of interannual variability. Henson et al. [2009] used output from an ocean ecosystem model in a GCM to demonstrate that variations in atmospheric forcing (wind, surface heat and freshwater fluxes) affected the timing of the spring bloom via changes in mixed layer depth (MLD). They found that periods of positive N. Atlantic Oscillation index correlated with deep MLDs that delayed onset of the spring bloom. There is strong seasonality in the region. At a site in the northeast subpolar N. Atlantic $\left(49^{\circ} \mathrm{N} 17^{\circ} \mathrm{W}\right)$ with two years of continuous mooring-based measurements, Körtzinger et al. [2008] found that between winter and summer mixed layer depths shoaled from $500 \mathrm{~m}$ to $20 \mathrm{~m}$, nitrate decreased from $\sim 8$ to $0 \mu \mathrm{mol} \mathrm{kg}^{-1}$, chlorophyll increased from $\sim 0.2$ to $2 \mathrm{ug} \mathrm{L^{-1 }}$ and $\mathrm{pCO}_{2}$ decreased from $\sim 360$ to $300 \mu \mathrm{atm}$ in the surface layer. These strong seasonal variations indicate that the occasional snapshot of PP in the N. Atlantic will be insufficient to determine the annual mean rate.

[8] Estimating the rates of PP and NCP during the spring bloom in the subpolar N. Atlantic $\left(47^{\circ} \mathrm{N} 20^{\circ} \mathrm{W}\right)$ was a major focus of the N. Atlantic Bloom Experiment (NABE) study in May 1989 (see Tables 1 and 2). Martin et al. [1993] measured ${ }^{14} \mathrm{C}-\mathrm{PP}$ rates and found a mean of $90 \pm 13 \mathrm{mmol} \mathrm{C}$ $\mathrm{m}^{-2} \mathrm{~d}^{-1}\left(1080 \pm 153 \mathrm{mg} \mathrm{C} \mathrm{m} \mathrm{m}^{-1}\right)$. (Uncertainties in mean values represent error in the mean at $95 \%$ confidence level $(\sim 2 \mathrm{SD} / \sqrt{ } \mathrm{n})$ unless indicated otherwise.) One year later during May 1990 at the NABE site, Bury et al. [2001] measured a mean ${ }^{14} \mathrm{C}$-PP rate of $70 \pm 30 \mathrm{mmol} \mathrm{C} \mathrm{m}{ }^{-2}$ $\mathrm{d}^{-1}\left(840 \pm 350 \mathrm{mg} \mathrm{C} \mathrm{m}^{-2} \mathrm{~d}^{-1}\right)$ at 8 stations while tracking a parcel of water over 18 days and found that diatoms dominated during the first half of the measurement interval under 
Table 2. Estimates of Net Community Production in $\mathrm{mmol} \mathrm{C} \mathrm{m}{ }^{-2}$ $\mathrm{d}^{-1}$ in Mixed Layer, Unless Noted Otherwise, in the Subpolar N. Atlantic and Other Oceanic Regions

\begin{tabular}{|c|c|c|}
\hline Site & Rate & Method \\
\hline \multicolumn{3}{|c|}{ Subpolar N. Atlantic } \\
\hline \multicolumn{3}{|l|}{$\operatorname{NABE}\left(49^{\circ} \mathrm{N} 17^{\circ} \mathrm{W}\right)$} \\
\hline \multirow[t]{8}{*}{ May 1989} & $5-40$ & ${ }^{234} \mathrm{Th}_{\text {budget }}{ }^{\mathrm{a}}$ \\
\hline & $34-42$ & Diurnal $\mathrm{CO}_{2}{ }^{\mathrm{b}}$ \\
\hline & 36 & $\mathrm{NO}_{3}$ drawdown ${ }^{\mathrm{c}}$ \\
\hline & $82 \pm 17$ & DIC drawdown ${ }^{\mathrm{d}}$ \\
\hline & 52 & $\mathrm{NO}_{3}$ drawdown $^{\mathrm{e}}$ \\
\hline & 37 & $\mathrm{PO}_{4}$ drawdown ${ }^{\mathrm{e}}$ \\
\hline & 90 & $\mathrm{O}_{2}$ budget $^{\mathrm{e}}$ \\
\hline & 52 & POC budget ${ }^{\mathrm{e}}$ \\
\hline \multicolumn{3}{|l|}{$\operatorname{PAP}\left(49^{\circ} \mathrm{N} 17^{\circ} \mathrm{W}\right)$} \\
\hline Spring (Mar-May, 2004-05) & 70 & DIC drawdown ${ }^{\mathrm{f}}$ \\
\hline Summer (May-Sep, 2004-05) & 25 & DIC drawdown ${ }^{\mathrm{f}}$ \\
\hline Annual (at $238 \mathrm{~m}$ ) & $10 \pm 8$ & DIC drawdown ${ }^{\mathrm{f}}$ \\
\hline \multicolumn{3}{|l|}{ This Study } \\
\hline $\begin{array}{l}\text { Spring Bloom May } 2008 \\
\left(61^{\circ} \mathrm{N} 26^{\circ} \mathrm{W}\right)\end{array}$ & $62 \pm 9$ & $\mathrm{O}_{2}+\mathrm{Ar}_{\text {budgets }}{ }^{\mathrm{g}}$ \\
\hline $\begin{array}{l}\text { Annual Basin Wide at Winter } \\
\quad \operatorname{MLD}\left(40^{\circ}-65^{\circ} \mathrm{N}\right)\end{array}$ & $8 \pm 7$ & $\mathrm{O}_{2}$ budget $^{\mathrm{g}}$ \\
\hline \multicolumn{3}{|c|}{ Other Oceanic Regions } \\
\hline Subtropical N. Pacific (HOT) & $8 \pm 4$ & $\begin{array}{l}\mathrm{O}_{2}+\text { Ar, DIC }+\mathrm{DIC}^{13} \\
\text { budgets }^{\mathrm{h}}\end{array}$ \\
\hline Subtropical N. Atlantic (BATS) & $6-11$ & $\begin{array}{l}\mathrm{O}_{2}+\text { Ar, DIC+DIC } \\
\text { budgets } \\
\text { h,i }\end{array}$ \\
\hline Subarctic N. Pacific & $6-12$ & $\begin{array}{l}\mathrm{O}_{2} \text { budget, } \mathrm{NO}_{3} \\
\text { drawdown }\end{array}$ \\
\hline Equatorial Pacific & $7 \pm 6$ & $\begin{array}{l}\mathrm{O}_{2}+\text { Ar, DIC }+\mathrm{DIC}^{13} \\
\text { budgets }^{\mathrm{h}, \mathrm{j}, \mathrm{k}}\end{array}$ \\
\hline Southern Ocean & $16-36$ & $\mathrm{O}_{2}+\mathrm{Ar}$ budget ${ }^{1}$ \\
\hline Coast of California & $30 \pm 10$ & $\mathrm{O}_{2}+$ Ar budget ${ }^{\mathrm{m}}$ \\
\hline
\end{tabular}

${ }^{\mathrm{a}}$ Buesseler et al. [1992].

${ }^{\mathrm{b}}$ Robertson et al. [1993].

${ }^{\mathrm{c}}$ Sambrotto et al. [1993].

${ }^{\mathrm{d}}$ Chipman et al. [1993].

${ }^{\mathrm{e}}$ Bender et al. [1992].

${ }^{\mathrm{f}}$ Körtzinger et al. [2008]

${ }^{\mathrm{g}}$ This study.

${ }^{\mathrm{h}}$ Compiled by Emerson et al. [2008].

${ }^{\mathrm{i}}$ Luz and Barkan [2009].

${ }^{\mathrm{j}}$ Hendricks et al. [2005].

${ }^{\mathrm{k}}$ Stanley et al. [2010].

${ }^{1}$ Reuer et al. [2007].

${ }^{\mathrm{m}}$ Munro et al. (submitted 2012).

bloom conditions and flagellates dominated during the post bloom phase over the second half of the interval. Joint et al. [1993] measured ${ }^{14} \mathrm{C}-\mathrm{PP}$ rates at 28 stations between $47^{\circ} \mathrm{N}$ and $60^{\circ} \mathrm{N}$ along $\sim 20^{\circ} \mathrm{W}$ during May, June and July 1990 and found mean rates of $48 \pm 12,53 \pm 11$ and $36 \pm 3 \mathrm{mmol}$ $\mathrm{C} \mathrm{m}^{-2} \mathrm{~d}^{-1}\left(580 \pm 140,639 \pm 124\right.$ and $425 \pm 33 \mathrm{mg} \mathrm{C} \mathrm{m}^{-2}$ $\mathrm{d}^{-1}$ ), respectively. During the POMME experiment in 2001 $\left(38^{\circ}-45^{\circ} \mathrm{N}, 16^{\circ}-22^{\circ} \mathrm{W}\right)$, Fernandez et al. [2005] measured PP rates at $\sim 25$ stations (using on-deck $12 \mathrm{~h}{ }^{13} \mathrm{C}$ incubations) of $38 \pm 7,103 \pm 17$ and $35 \pm 4 \mathrm{mmol} \mathrm{C} \mathrm{m} \mathrm{C} \mathrm{d}^{-2}$ $\left(456 \pm 81,1236 \pm 202\right.$ and $\left.420 \pm 51 \mathrm{mg} \mathrm{C} \mathrm{m}^{-2} \mathrm{~d}^{-1}\right)$ during winter (Jan-Feb), spring (Mar-Apr) and summer (Aug-Sep), respectively.

[9] Bender et al. [1992] measured PP during NABE using both ${ }^{14} \mathrm{C}$ (daytime and $24 \mathrm{~h}$ incubations) and ${ }^{18} \mathrm{O}$ bottle incubation methods, where the latter technique measures the gross oxygen production rate [Bender et al., 1987]. Bender et al. [1992] found that the mean ${ }^{18} \mathrm{O}$-based GOP rate of $206 \mathrm{mmol} \mathrm{O}_{2} \mathrm{~m}^{-2} \mathrm{~d}^{-1}$ was $2.5 \times$ the $24 \mathrm{~h}{ }^{14} \mathrm{C}$-PP rate of
$84 \pm 14 \mathrm{mmol} \mathrm{C} \mathrm{m}^{-2} \mathrm{~d}^{-1}\left(1008 \pm 168 \mathrm{mg} \mathrm{C} \mathrm{m}^{-2} \mathrm{~d}^{-1}\right)$ and double the daytime ${ }^{14} \mathrm{C}$-PP rate measured at 13 stations over two weeks. These results agree well with the ${ }^{18} \mathrm{O}-\mathrm{GOP} /{ }^{14} \mathrm{C}$ $\mathrm{PP}(24 \mathrm{~h})$ ratio of $2.7 \pm 0.2$ and ${ }^{18} \mathrm{O}-\mathrm{GOP} /{ }^{14} \mathrm{C}-\mathrm{PP}$ (daytime) ratio of $2.0 \pm 0.2$ observed during subsequent JGOFS process studies in the equatorial Pacific and Arabian Sea and, more recently, at station ALOHA in the subtropical N. Pacific [Bender et al., 1999; Marra, 2002; Quay et al., 2010].

[10] The strong annual cycle in PP in the subpolar $\mathrm{N}$. Atlantic is most clearly demonstrated by the extensive ${ }^{14} \mathrm{C}$-PP data set ( $\sim 700$ depth profiles) collected during the Marine Monitoring, Assessment and Prediction (MARMAP) program in the Gulf of Maine and Georges Bank $\left(40^{\circ}-42^{\circ} \mathrm{N}\right.$; $68^{\circ}-73^{\circ} \mathrm{W}$ ) between 1977 and 1982. Summertime (JunAug) mean ${ }^{14} \mathrm{C}$-PP levels at $101 \pm 15 \mathrm{mmol} \mathrm{C} \mathrm{m}{ }^{-2} \mathrm{~d}^{-1}$ $\left(1211 \pm 184 \mathrm{mg} \mathrm{C} \mathrm{m}^{-2} \mathrm{~d}^{-1}\right)$ exceeded by $\sim 3 \times$ wintertime (Dec-Feb) mean rate of $31 \pm 9 \mathrm{mmol} \mathrm{C} \mathrm{m}{ }^{-2} \mathrm{~d}^{-1}(371 \pm$ $106 \mathrm{mg} \mathrm{C} \mathrm{m}^{-2} \mathrm{~d}^{-1}$ ). The onset of the spring bloom during MARMAP is seen clearly in March by a sharp increase from winter levels in ${ }^{14} \mathrm{C}-\mathrm{PP}$ to $1016 \pm 353 \mathrm{mg} \mathrm{C} \mathrm{m}^{-2} \mathrm{~d}^{-1}$ and chlorophyll to $3.5 \mathrm{ug} \mathrm{L} \mathrm{L}^{-1} \cdot{ }^{14} \mathrm{C}$-PP correlated strongly with irradiance which accounted for $\sim 70 \%$ of monthly variability in ${ }^{14} \mathrm{C}-\mathrm{PP}\left(\mathrm{r}^{2}=0.67, \mathrm{P}<0.001\right)$ but insignificantly with chlorophyll $\left(\mathrm{r}^{2}=0.02, \mathrm{P}=0.7\right)$. Such an extensive ${ }^{14} \mathrm{C}-\mathrm{PP}$ data set is rare and thus the MARMAP data set has been used extensively to calibrate the satellite PP algorithms (e.g., the VGPM by Behrenfeld and Falkowski [1997]). However, it is not clear how well the annual cycle in ${ }^{14} \mathrm{C}-\mathrm{PP}$ measured during MARMAP in a coastal region represents PP in the open subpolar N Atlantic.

[11] Rates of NCP in the subpolar N. Atlantic were estimated by several methods during NABE (Table 2). Buesseler et al. [1992] used ${ }^{234}$ Th budget to estimate a POC export rate that varied from $5-40 \mathrm{mmol} \mathrm{C} \mathrm{m} \mathrm{m}^{-2} \mathrm{~d}^{-1}$. Chipman et al. [1993] estimated NCP of $82 \pm 17 \mathrm{mmol} \mathrm{C}$ $\mathrm{m}^{-2} \mathrm{~d}^{-1}$ for the mixed layer based on the rate of DIC drawdown. Robertson et al. [1993] used measured diurnal changes in $\mathrm{pCO}_{2}$ and $\mathrm{O}_{2}$ to estimate an NCP of 34-42 mmol $\mathrm{C} \mathrm{m}{ }^{-2} \mathrm{~d}^{-1}$ and $33-53 \mathrm{mmol} \mathrm{O}_{2} \mathrm{~m}^{-2} \mathrm{~d}^{-1}$, respectively. Sambrotto et al. [1993] estimated NCP of $36 \mathrm{mmol} \mathrm{C} \mathrm{m}^{-2}$ $\mathrm{d}^{-1}$ based on the measured nitrate drawdown between April and August off Iceland $\left(60^{\circ} \mathrm{N} 20^{\circ} \mathrm{W}\right)$. Bender et al. [1992] estimated rates of $52,37,52$ and $90 \mathrm{mmol} \mathrm{C} \mathrm{m} \mathrm{d}^{-1}$ based on measured nitrate and phosphate drawdown and POC and $\mathrm{O}_{2}$ budgets, respectively. Comparing these estimates of $\mathrm{NCP}$ to measured ${ }^{14} \mathrm{C}-\mathrm{PP}$ during $\mathrm{NABE}$ $\left(\sim 90 \mathrm{mmol} \mathrm{C} \mathrm{m}{ }^{-2} \mathrm{~d}^{-1}\right)$ yields an estimate of the potential export efficiency or e-ratio $\left(\mathrm{NCP} /{ }^{14} \mathrm{C}-\mathrm{PP}\right)$ that ranged from 0.4 and 1.0. The ratio of new to net PP (i.e., f-ratio) was estimated at 0.3 in winter, spring and summer during POMME by [Fernandez et al., 2005] and at $0.68 \pm 0.11$ during JGOFS by Bury et al. [2001] based on ${ }^{15} \mathrm{NO}_{3}$ and ${ }^{13} \mathrm{CO}_{2}$ uptake rates. Although these studies significantly improved our understanding of $\mathrm{PP}$ and $\mathrm{OC}$ export during the spring bloom in the subpolar N. Atlantic, the annual cycle was still poorly understood.

[12] A clearer picture of the annual cycle in NCP was obtained by Körtzinger et al. [2008], who used a two year record (2003-2005) of mooring-based measurements of $\mathrm{pCO}_{2}$ and nitrate at a study site $\left(\mathrm{PAP}\right.$ at $49^{\circ} \mathrm{N} 17^{\circ} \mathrm{W}$ ) close to the NABE site to quantify the impact of NCP on the air-sea 
$\mathrm{CO}_{2}$ flux. There was a clear spring and summer drawdown of $\mathrm{CO}_{2}$ and nitrate while the mixed layer shoaled from winter time depths of $\sim 500 \mathrm{~m}$ to $\sim 30 \mathrm{~m}$ during summer. Körtzinger et al. estimated an NCP of $\sim 70 \mathrm{mmol} \mathrm{C} \mathrm{m}{ }^{-2} \mathrm{~d}^{-1}$ during the spring bloom interval (Mar-May), which compared well with estimates during NABE, and $25 \mathrm{mmol} \mathrm{C} \mathrm{m}{ }^{-2} \mathrm{~d}^{-1}$ during the subsequent stratified period (May-Sep) based on DIC drawdown. However, despite the high NCP rates from the mixed layer during spring and summer in the subpolar N. Atlantic the impact on annual OC export is substantially reduced. Körtzinger et al.'s two yearlong $\mathrm{pCO}_{2}$ record indicates that $40 \%$ of the OC exported below the summertime mixed layer is respired and released as $\mathrm{CO}_{2}$ to the atmosphere during the following fall and winter when the mixed layer deepens.

[13] In summary, the subpolar $\mathrm{N}$. Atlantic is a region of high biological productivity, atmospheric $\mathrm{CO}_{2}$ uptake, interannual variability, seasonality and climate sensitivity. Our knowledge of spatial and temporal variations in biological productivity needs improvement to better understand the response of the $\mathrm{CO}_{2}$ cycle in the region to climate change and provide data for validating carbon cycle models and satellite-based productivity estimates.

\section{Methods}

\subsection{Oxygen Isotope Based GOP}

[14] The oxygen isotope method to estimate gross photosynthetic oxygen production rate (GOP) has been thoroughly described previously [e.g., Luz and Barkan, 2000; Hendricks et al., 2004]. The basis of the method relies on the observation that atmospheric $\mathrm{O}_{2}$ has an anomalously low ${ }^{17} \mathrm{O} /{ }^{18} \mathrm{O}$ relative to $\mathrm{O}_{2}$ produced photosynthetically. Thus by measuring the ${ }^{17} \mathrm{O} /{ }^{16} \mathrm{O}$ and ${ }^{18} \mathrm{O} /{ }^{16} \mathrm{O}$ of $\mathrm{O}_{2}$ dissolved in seawater, one obtains the fractions of $\mathrm{O}_{2}$ derived from air and from photosynthesis. Coupling this $\mathrm{O}_{2}$ isotope measurement with an estimate of the air-sea $\mathrm{O}_{2}$ gas transfer rate typically from a wind speed based parameterization [e.g., Nightingale et al., 2000] yields a GOP estimate integrated to the base of the mixed budget [Luz and Barkan, 2000].

[15] The oxygen isotope anomaly $\left({ }^{17} \Delta\right)$ is defined as

$$
\begin{aligned}
{ }^{17} \Delta(\text { per meg })= & 10^{6} *\left[\ln \left(\delta^{17} \mathrm{O} / 1000-1\right)\right. \\
& \left.\left.-\gamma^{*} \ln \left(\delta^{18} \mathrm{O} / 1000-1\right)\right)\right]
\end{aligned}
$$

where $\delta^{17} \mathrm{O}$ and $\delta^{18} \mathrm{O}$ are defined using standard delta notation and $\gamma$ is 0.518 [Luz and Barkan, 2005]. Deviations are small and are measured in units of per meg (where 1 per meg $=0.001 \%)$ and atmospheric $\mathrm{O}_{2}$ is the standard $\left({ }^{17} \Delta=\right.$ 0 per meg). $\mathrm{O}_{2}$ produced by photosynthesis in seawater has a positive ${ }^{17} \Delta$ of 249 per meg $\left({ }^{17} \Delta_{\text {photo }}\right)$ relative to $\mathrm{O}_{2}$ in air [Luz and Barkan, 2000]. Dissolution of atmospheric $\mathrm{O}_{2}$ in seawater imparts a small but measurable ${ }^{17} \Delta$ anomaly $\left({ }^{17} \Delta_{\text {eq }}\right)$ of $7-16$ per meg depending on temperature [ $[$ uz and Barkan, 2009]. Importantly, respiration has no effect on ${ }^{17} \Delta$ of dissolved $\mathrm{O}_{2}\left({ }^{17} \Delta_{\text {diss }}\right)$ because it consumes $\mathrm{O}_{2}$ with a ${ }^{17} \mathrm{O} /{ }^{18} \mathrm{O}$ of 0.518 [Luz and Barkan, 2005; Helman et al., 2005]. Thus the ${ }^{17} \Delta_{\text {diss }}$ of dissolved $\mathrm{O}_{2}$ in the surface mixed layer primarily depends on gross, rather than net, primary production and air-sea gas exchange.

[16] The ${ }^{17} \Delta_{\text {diss }}$ in the surface ocean falls between a possible range of $\sim 7$ and 249 per meg, with higher values indicating a larger contribution of photosynthetic $\mathrm{O}_{2}$. Luz and Barkan [2000] showed that the rate of GOP $\left(\mathrm{mmol} \mathrm{O}_{2}\right.$ $\mathrm{m}^{-2} \mathrm{~d}^{-1}$ ) integrated to the base of the mixed layer can be determined by measuring the ${ }^{17} \Delta_{\text {diss }}$, calculating the expected concentration of $\mathrm{O}_{2}$ at saturation with air $\left(\mathrm{O}_{2 \text { sat }}\right.$, $\mathrm{mmol} \mathrm{m}{ }^{-3}$ ) and estimating the air-sea $\mathrm{O}_{2}$ gas transfer rate $\left(\mathrm{k}_{\mathrm{g}}, \mathrm{m} \mathrm{d}^{-1}\right)$. GOP can be approximated by the following expression [Luz and Barkan, 2000]:

$$
\mathrm{GOP}=\mathrm{k}_{\mathrm{g}} * \mathrm{O}_{2 \text { sat }} *\left({ }^{17} \Delta_{\text {diss }}-{ }^{17} \Delta_{\text {eq }}\right) /\left({ }^{17} \Delta_{\text {photo }}-{ }^{17} \Delta_{\text {diss }}\right)
$$

Recently, the procedure to calculate GOP from ${ }^{17} \Delta$ has been revised to improve its accuracy [Kaiser, 2011; Nicholson, 2011; Prokopenko et al., 2011; Luz and Barkan, 2011]. The revised procedure calculates GOP as a function of the ${ }^{18} \mathrm{O} /{ }^{16} \mathrm{O}$ and ${ }^{17} \mathrm{O} /{ }^{16} \mathrm{O}$ of dissolved $\mathrm{O}_{2}$ directly, rather than in terms of ${ }^{17} \Delta$. We use this revised procedure as described by Luz and Barkan [2011] to calculate GOP. We find that the basin-wide mean GOP differs by $-10 \%$ to $+16 \%$ on individual cruises ( $3 \%$ on average) from the previous method (equation (2)).

[17] The ${ }^{17} \Delta$-GOP estimate relies on simple mixed-layer $\mathrm{O}_{2}$ mass and isotope budgets that assumes steady state and neglects transport via physical processes like mixing, entrainment and advection. However, under certain conditions, e.g., where upwelling is strong or during a period of mixed layer deepening, the ${ }^{17} \Delta_{\text {diss }}$ of the mixed layer can be elevated significantly by physical processes (rather than in situ photosynthesis) and result in an overestimate of GOP [e.g., Juranek and Quay, 2010; Quay et al., 2010], as discussed below.

[18] Previously, estimates of ${ }^{14} \mathrm{C}-\mathrm{PP}$ have been derived from ${ }^{17} \Delta$-GOP using the ratio of ${ }^{18} \mathrm{O}$-GOP to ${ }^{14} \mathrm{C}$-PP measured during simultaneous bottle incubations [Hendricks et al., 2005; Reuer et al., 2007; Luz and Barkan, 2009; Juranek and Quay, 2010; Quay et al., 2010]. A mean ${ }^{18} \mathrm{O}-$ GOP $\left(\mathrm{mmol} \mathrm{O} \mathrm{O}_{2} \mathrm{~m}^{-2} \mathrm{~d}^{-1}\right) /{ }^{14} \mathrm{C}-\mathrm{PP}\left(\mathrm{mmol} \mathrm{C} \mathrm{m} \mathrm{m}^{-2} \mathrm{~d}^{-1}\right)$ of $2.7 \pm 0.2$ was observed during the three separate JGOFS process studies in subpolar N. Atlantic, equatorial Pacific and Arabian sea [Marra, 2002], where ${ }^{14} \mathrm{C}-\mathrm{PP}$ represents $24 \mathrm{~h}$ incubations. In the present study an equivalent daily (24 h) ${ }^{14} \mathrm{C}$-PP rate $\left({ }^{14} \mathrm{C}-\mathrm{PP}\right.$ eqv $)$ equals ${ }^{17} \Delta$-GOP/2.7.

\section{2. $\mathrm{O}_{2} / \mathrm{Ar}$ Based NCP and NCP/GOP}

[19] The net imbalance between gross PP and community respiration can be estimated from a mixed layer budget for dissolved oxygen. In its simplest form, the budget assumes that the net rate of $\mathrm{O}_{2}$ gas evasion to the atmosphere is balanced by net biological $\mathrm{O}_{2}$ production (i.e., GOP - R). Emerson et al. [1997] utilized the similar temperature dependence of gas solubility in seawater for Argon (Ar) and $\mathrm{O}_{2}$ to determine the biological component of the $\mathrm{O}_{2}$ gas flux. In this way, the $\mathrm{O}_{2} / \mathrm{Ar}$ saturation state (i.e., $\left(\mathrm{O}_{2} / \mathrm{Ar}\right)_{\text {sat }}$ which equals the $\mathrm{O}_{2} / \mathrm{Ar}$ measured divided by the $\mathrm{O}_{2} / \mathrm{Ar}$ expected in equilibrium with air) yielded the portion of the net sea to air $\mathrm{O}_{2}$ flux that was balanced by $\mathrm{O}_{2}$ production from NCP. Thus $\mathrm{NCP}$ in the mixed layer is determined from measuring the ratio of dissolved $\mathrm{O}_{2}$ and Ar gases, calculating $\left(\mathrm{O}_{2} / \mathrm{Ar}\right)_{\text {sat }}$ and estimating $\mathrm{k}_{\mathrm{g}}$, as follows:

$$
\left.\mathrm{NCP}=\mathrm{k}_{\mathrm{g}} \cdot \mathrm{O}_{2 \mathrm{sat}} \cdot\left[\left(\mathrm{O}_{2} / \mathrm{Ar}\right)_{\mathrm{sat}}-1\right)\right]
$$


Table 3. Estimates of NCP/PP e-ratio in the Subpolar N. Atlantic and Other Ocean Regions

\begin{tabular}{|c|c|c|c|}
\hline Site & $\mathrm{NCP} / \mathrm{PP}$ & Method & Reference \\
\hline \multicolumn{4}{|c|}{ Subpolar N. Atlantic } \\
\hline \multicolumn{4}{|l|}{$\operatorname{NABE}\left(49^{\circ} \mathrm{N} 17^{\circ} \mathrm{W}\right)$} \\
\hline May 1989 & $1.0^{\mathrm{a}}$ & $\triangle \mathrm{DIC} /{ }^{14} \mathrm{C}-\mathrm{PP}$ & Chipman et al. [1993] \\
\hline & $0.20-0.46^{\mathrm{a}}$ & ${ }^{15} \mathrm{NO}_{3} /{ }^{14} \mathrm{C}-\mathrm{PP}$ & Sambrotto et al. [1993] \\
\hline & $0.71^{\mathrm{a}}$ & $\Delta \mathrm{NO}_{3} /{ }^{14} \mathrm{C}-\mathrm{PP}$ & Bender et al. [1992] \\
\hline & $0.51^{\mathrm{a}}$ & $\triangle \mathrm{PO}_{4} /{ }^{14} \mathrm{C}-\mathrm{PP}$ & Bender et al. [1992] \\
\hline & $0.71^{\mathrm{a}}$ & $\triangle \mathrm{POC} /{ }^{14} \mathrm{C}-\mathrm{PP}$ & Bender et al. [1992] \\
\hline & $1.0^{\mathrm{a}}$ & $\Delta \mathrm{O}_{2} /{ }^{14} \mathrm{C}-\mathrm{PP}$ & Bender et al. [1992] \\
\hline \multicolumn{4}{|l|}{ JGOFS $\left(47^{\circ} \mathrm{N} 20^{\circ} \mathrm{W}\right)$} \\
\hline May 1990 & $0.68 \pm 0.11^{\mathrm{a}}$ & ${ }^{15} \mathrm{NO}_{3} /{ }^{14} \mathrm{C}-\mathrm{PP}$ & Bury et al. [2001] \\
\hline \multicolumn{4}{|l|}{ POMMES $\left(38^{\circ}-45^{\circ} \mathrm{N}, 17^{\circ}-22^{\circ} \mathrm{W}\right)$} \\
\hline Jan-Feb 2001 & $0.28^{\mathrm{a}}$ & ${ }^{15} \mathrm{NO}_{3} /{ }^{13} \mathrm{C}-\mathrm{PP}$ & Fernandez et al. [2005] \\
\hline Mar-Apr 2001 & $0.34^{\mathrm{a}}$ & ${ }^{15} \mathrm{NO}_{3} /{ }^{13} \mathrm{C}-\mathrm{PP}$ & Fernandez et al. [2005] \\
\hline Aug-Sep 2001 & $0.25^{\mathrm{a}}$ & ${ }^{15} \mathrm{NO}_{3} /{ }^{13} \mathrm{C}-\mathrm{PP}$ & Fernandez et al. [2005] \\
\hline \multicolumn{4}{|l|}{ This Study } \\
\hline \multirow[t]{2}{*}{ May $2008\left(60^{\circ} \mathrm{N} 17^{\circ} \mathrm{W}\right)$} & $0.35 \pm 0.07^{\mathrm{b}}$ & $\mathrm{O}_{2} / \mathrm{Ar}-\mathrm{NCP} /{ }^{17} \Delta$-GOP & \\
\hline & $0.70 \pm 0.14^{\mathrm{c}}$ & $\mathrm{NCP} /{ }^{14} \mathrm{C}-\mathrm{PP}$ eqv & \\
\hline Basin-wide $\left(40^{\circ}-65^{\circ} \mathrm{N}\right)$ & $0.07 \pm 0.06^{\mathrm{b}}$ & $\mathrm{O}_{2}-\mathrm{NCP} /{ }^{17} \Delta-\mathrm{GOP}$ & \\
\hline \multirow[t]{2}{*}{ Annual (winter MLD) } & $0.14 \pm 0.12^{\mathrm{c}}$ & $\mathrm{NCP} /{ }^{14} \mathrm{C}-\mathrm{PP}_{\mathrm{eqv}}$ & \\
\hline & \multicolumn{2}{|c|}{ Other Oceanic Regions } & \\
\hline Subtropical N. Atl. (BATS) & $0.13 \pm 0.05^{\mathrm{b}}\left(0.26 \pm 0.10^{\mathrm{c}}\right)$ & $\mathrm{O}_{2} / \mathrm{Ar}-\mathrm{NCP} /{ }^{17} \mathrm{D}-\mathrm{GOP}$ & Luz and Barkan [2009] \\
\hline Subtropical N. Pac. (HOT) & $0.19 \pm 0.08^{b}\left(0.38 \pm 0.16^{c}\right)$ & $\mathrm{O}_{2} / \mathrm{Ar}-\mathrm{NCP} /{ }^{17} \mathrm{D}-\mathrm{GOP}$ & Quay et al. [2010] \\
\hline Equatorial Pacific & $0.06 \pm 0.05^{\mathrm{b}}\left(0.12 \pm 0.10^{\mathrm{c}}\right)$ & $\mathrm{O}_{2} / \mathrm{Ar}-\mathrm{NCP} /{ }^{17} \mathrm{D}-\mathrm{GOP}$ & $\begin{array}{l}\text { Hendricks et al. } \\
\text { Stanley et al. }[2010]\end{array}$ \\
\hline Southern Ocean & $0.13 \pm 0.06^{\mathrm{b}}\left(0.26 \pm 0.12^{\mathrm{c}}\right)$ & $\mathrm{O}_{2} / \mathrm{Ar}-\mathrm{NCP} /{ }^{17} \mathrm{D}-\mathrm{GOP}$ & Reuer et al. [2007] \\
\hline Coastal off S. California & $0.14 \pm 0.09^{\mathrm{b}}\left(0.30 \pm 0.34^{\mathrm{c}}\right)$ & $\mathrm{O}_{2} / \mathrm{Ar}-\mathrm{NCP} /{ }^{17} \mathrm{D}-\mathrm{GOP}$ & Munro et al. (submitted, 2012) \\
\hline
\end{tabular}

NCP (mmol C m $\left.{ }^{-2} \mathrm{~d}^{-1}\right)$ has been estimated based on $\mathrm{O}_{2} / \mathrm{Ar}$ measurements in several ocean regions (Table 2) and averaged $8 \pm 4$ at HOT [Emerson et al., 1997; Hamme and Emerson, 2006; Quay et al., 2010], 6-11 at BATS [Luz and Barkan, 2009], $7 \pm 6$ in the equatorial Pacific [Hendricks et al., 2005; Stanley et al., 2010], 16-36 for the Southern Ocean [Reuer et al., 2007] and $30 \pm 10$ off the coast of southern California (D. R. Munro et al., Biological production rates off the Southern California coast estimated from triple $\mathrm{O}_{2}$ isotopes and $\mathrm{O}_{2}$ :Ar gas ratios, submitted to Limnology and Oceanography, 2012). Typically, net biological oxygen production is divided by 1.4 to convert to net organic carbon production assuming the net production is supported by nitrate. The rates of NCP and OC export are assumed equivalent implying steady state.

[20] The NCP/GOP in the mixed layer can be estimated by simultaneous ${ }^{17} \Delta$ and $\mathrm{O}_{2} / \mathrm{Ar}$ measurements (combining equations (2) and (3)) and can be approximated by the following relationship:

$$
\begin{aligned}
\mathrm{NCP} / \mathrm{GOP}= & {\left[\left(\mathrm{O}_{2} / \mathrm{Ar}\right)_{\text {sat }}-1\right] } \\
& \cdot\left({ }^{17} \Delta_{\text {photo }}-{ }^{17} \Delta_{\text {diss }}\right) /\left({ }^{17} \Delta_{\text {diss }}-{ }^{17} \Delta_{\text {eq }}\right)
\end{aligned}
$$

In practice, the more accurate revised GOP method, discussed above, is used to estimate NCP/GOP. Because NCP/ GOP is independent of $\mathrm{k}_{\mathrm{g}}$, the calculated NCP/GOP usually is less uncertain than either GOP or NCP (except when $\left(\mathrm{O}_{2} /\right.$ Ar) $)_{\text {sat }}$ approaches 1). The numerator and denominator of $\mathrm{NCP} / \mathrm{GOP}$ are measured in the same units of $\mathrm{O}_{2}$ production. Previous NCP/GOP estimates based on ${ }^{17} \Delta$ and $\mathrm{O}_{2} / \mathrm{Ar}$ measurements (Table 3 ) averaged $0.13 \pm 0.05$ at BATS [ Luz and Barkan, 2009], $0.19 \pm 0.08$ at HOT [Quay et al., 2010], $0.06 \pm 0.05$ in the equatorial Pacific [Hendricks et al., 2005;
Stanley et al., 2010], $0.13 \pm 0.06$ for the Southern Ocean [Reuer et al., 2007], and $0.14 \pm 0.09$ off the coast of southern California (Munro et al., submitted). To convert these e-ratio estimates from oxygen (NCP/GOP) to a carbon equivalent $\left(\mathrm{NCP} /{ }^{14} \mathrm{C}-\mathrm{PP}\right)$, the $\mathrm{NCP} / \mathrm{GOP}$ is multiplied by $\sim 2 \times$, i.e., $(\mathrm{NCP} / 1.4) /\left({ }^{17} \Delta-\mathrm{GOP} / 2.7\right)$.

\subsection{Sample Collection and Analysis}

[21] Samples were collected from the seawater intake (4$8 \mathrm{~m}$ depending on ship draft) during eastbound transits of the container ship M/V Atlantic Companion from Halifax, Nova Scotia to Liverpool, GB between March 2007 and June 2008 (Figure 1). Typically, 15-20 samples were collected over a 5 day interval on each cruise in the region bounded by $45^{\circ}-$ $55^{\circ} \mathrm{N}$ and $10^{\circ}$ to $60^{\circ} \mathrm{W}$ as part of the CARBOOCEAN program as described by Steinhoff et al. [2010]. Sea surface temperature (SST) and salinity were measured at time of sample collection. Samples for ${ }^{17} \Delta-\mathrm{O}_{2}$ and $\mathrm{O}_{2} / \mathrm{Ar}$ measurements were also collected during a research cruise off Iceland $\left(\sim 61^{\circ} \mathrm{N} 26^{\circ} \mathrm{W}\right)$ during May 2008 using Niskin bottles $(\mathrm{n}=32)$.

[22] Gas samples were prepared for mass spectrometric analysis by cryogenic removal of $\mathrm{H}_{2} \mathrm{O}$ and $\mathrm{CO}_{2}$ and chromatographic separation of $\mathrm{N}_{2}$ from the gas mixture [Barkan and $\mathrm{Luz}, 2003$ ]. The extracted $\mathrm{O}_{2}$ and $\mathrm{Ar}$ gas mixture was then repeatedly measured 75 times for $\delta^{17} \mathrm{O}$ and $\delta^{18} \mathrm{O}$ by simultaneous collection of masses 32, 33, and 34 and for $\mathrm{O}_{2} /$ Ar by sequential measurement of masses 32 and 40 on a Thermo MAT 253 isotope ratio mass spectrometer. The $\delta^{17} \mathrm{O}$ and $\delta^{18} \mathrm{O}$ is corrected for any dependence on $\mathrm{O}_{2} / \mathrm{Ar}$ and differential loss. Typical analytical precisions for $\delta^{17} \mathrm{O}$, $\delta^{18} \mathrm{O},{ }^{17} \Delta$ and $\mathrm{O}_{2} /$ Ar were $0.01 \%$, $0.01 \%$, 7.4 per meg and $0.17 \%$, respectively, where precisions represent \pm 1 SD 


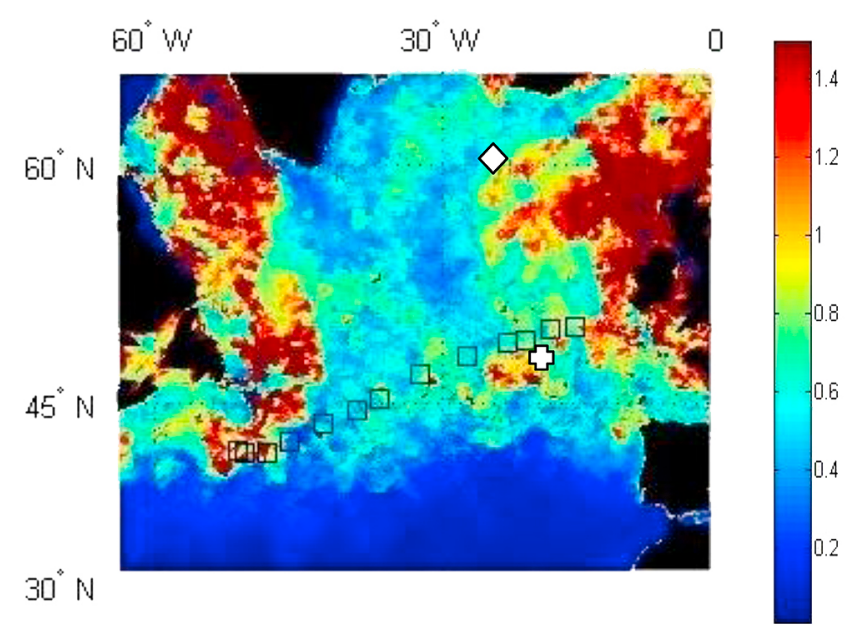

Figure 1. Cruise track of Atlantic Companion container ship where surface samples were collected (squares) in May 2008 and locations of research cruise in May 2008 off Iceland (diamond) and NABE (plus) (1989) superimposed on chlorophyll concentrations $\left(\mathrm{mg} \mathrm{m}^{-3}\right)$ from SeaWiFs in May 2008.

based on repeat measurements of an air standard run daily with seawater samples.

\section{4. $\mathrm{O}_{2} / \mathrm{Ar}$ Measurements: $\mathrm{O}_{2}$ Consumption in Seawater Sampling Line}

[23] The $\mathrm{O}_{2} / \mathrm{Ar}$ measurements indicated substantially undersaturated conditions, e.g., mean cruise $\left(\mathrm{O}_{2} / \mathrm{Ar}\right)_{\text {sat }}$ varied from 0.97 to 0.90 (i.e., 3 to $10 \%$ undersaturated), for samples collected on eight of the nine container ship cruises, even during summer when $\mathrm{O}_{2}$ supersaturation conditions are consistently observed (CARINA program) in the subpolar N. Atlantic [Stendardo et al., 2009]. A similar situation, but to a lesser degree, has been encountered previously for seawater samples collected underway on volunteer observing ships [Juranek et al., 2010]. Juranek et al. concluded that respiration within the seawater sampling line connecting the ship's intake pipe to the sampling port significantly reduced the $\mathrm{O}_{2} / \mathrm{Ar}$. (Note that Juranek et al. demonstrated that this situation can be avoided by treating the sampling line with bleach and freshwater.) The likelihood of in line respiration was further indicated by the build-up of material in the sampling line which caused significantly reduced flow rates observed during sample collection on some Atlantic Companion cruises. Thus the $\mathrm{O}_{2} / \mathrm{Ar}$ data collected during the Atlantic Companion cruises are compromised and will not be reported. Because ${ }^{17} \Delta$ has been defined (equation (1)) to eliminate a dependence on respiration, as discussed above, the ${ }^{17} \Delta$ values should not be affected by in line respiration.

[24] In contrast, during the research cruise in May 2008 on the R/V Knorr the seawater samples were collected using Niskin bottles and thus the $\mathrm{O}_{2} / \mathrm{Ar}$ results will be presented.

\subsection{Calculation of Air-Sea $\mathrm{O}_{2}$ Gas Transfer Rate}

[25] Remotely sensed wind speeds were used for determination the air-sea $\mathrm{O}_{2}$ gas transfer rate $\left(\mathrm{k}_{\mathrm{g}}\right)$ using daily QuikSCAT winds (at $0.25^{\circ} \times 0.25^{\circ}$ fields referenced to $10 \mathrm{~m}$ height, October 2006 reprocessing, available from the
NASA Jet Propulsion Lab Physical Oceanography Distributed Active Archive Center at http://podaac.jpl.nasa.gov/). The accuracy of QuikSCAT wind speeds has been tested by comparison to buoy data [Liu, 2002; Wentz et al., 2001] and found to be within $\pm 1 \mathrm{~m} \mathrm{~s}^{-1}$. Values of $\mathrm{k}_{\mathrm{g}}$ calculated using QuikSCAT winds were compared to those calculated using NCEP reanalysis winds during selected Atlantic Companion cruises and found to agree to better than $\pm 0.2 \mathrm{~m} \mathrm{~d}^{-1}$, which is well within the uncertainty of $\mathrm{k}_{\mathrm{g}}$, discussed below, and does not significantly increase the uncertainty in calculated GOP or NCP.

[26] Values for $\mathrm{k}_{\mathrm{g}}$ were determined using the Nightingale et al. [2000] wind speed parameterization. A weighted time-averaged $\mathrm{k}_{\mathrm{g}}$ at each sampling location was determined following a procedure similar to that used by Reuer et al. [2007].

\subsection{Estimates of Mixed Layer Depth, Chlorophyll and PAR}

[27] Mixed layer depths along the cruise track were determined from ARGO float data using the criteria of a temperature decrease of $0.2^{\circ} \mathrm{C}$ and potential density increase of $0.03 \mathrm{~kg} \mathrm{~m}^{-3}$ from the surface [Körtzinger et al., 2008]. At locations along the cruise track where ARGO float data were not available, MLD estimates were obtained from FNMOC as compiled by the Ocean Productivity group at Oregon State University (http://www.science.oregonstate.edu/ocean. productivity/). Chlorophyll concentrations and PAR were based on satellite derived estimates from SeaWIFS (cruises AC25-38, 49) and MODIS (Cruises AC45, 51) using the output from the Ocean Productivity group.

\subsection{Error Analysis and Biases}

[28] The uncertainty in the GOP, NCP and NCP/GOP estimated from ${ }^{17} \Delta$ and $\mathrm{O}_{2} / \mathrm{Ar}$ measurements was determined using a Monte Carlo approach following Quay et al. [2010]. The following errors $( \pm 1$ standard deviation or SD) in the terms were used: $\pm 25 \%$ for $\mathrm{k}_{\mathrm{g}}$, representing the $\mathrm{k}_{\mathrm{g}}$ range between Liss and Merlivat [1986] and Wanninkhof [1992] for observed wind speeds, \pm 8 per meg for ${ }^{17} \Delta_{\text {diss }}, \pm$ 15 per meg for ${ }^{17} \Delta_{\text {photo }}$ and \pm 3 per meg for ${ }^{17} \Delta_{\text {eq }}[$ Luz and Barkan, 2009], $\pm 0.2 \%$ for $\mathrm{O}_{2 \mathrm{eq}}$ and $\pm 0.2 \%$ for $\left(\mathrm{O}_{2} / \mathrm{Ar}\right)_{\mathrm{sat}}$. A Monte Carlo analysis yielded errors $( \pm 1 \mathrm{SD})$ of $\pm 45 \%$, $\pm 25 \%$ and \pm 0.1 for individual estimates of GOP, NCP and $\mathrm{NCP} / \mathrm{GOP}$, respectively.

[29] Note that the errors in mean GOP, NCP and NCP/ GOP values are smaller than the error in individual estimates. For example, if the mean and SD of 16 individual ${ }^{17} \Delta_{\text {diss }}$ measurements is $40 \pm 8$ per meg, the uncertainty in the mean (at $95 \%$ confidence level, SEM $=\sim 2 \mathrm{SD} / \sqrt{ } \mathrm{n}$ ) is \pm 4 per meg and the error in corresponding mean ${ }^{17} \Delta$-GOP due to only ${ }^{17} \Delta$ measurement uncertainty is halved from $\sim \pm 33 \%$ to $\pm 17 \%$. Typically, the SEM of the mean ${ }^{17} \Delta$ for each cruise was about half the SD of the ${ }^{17} \Delta$ values (i.e., $\mathrm{n} \sim 20$ ).

[30] During the fall, ${ }^{17} \Delta$-GOP rates can be overestimated due to the entrainment of subsurface water with high ${ }^{17} \Delta$ levels into the mixed layer as observed at station ALOHA [Quay et al., 2010]. The magnitude of the entrainment bias in GOP depends on the magnitude by which the subsurface ${ }^{17} \Delta$ exceeds the mixed layer ${ }^{17} \Delta$ in the fall. During the present study, the mean mixed layer ${ }^{17} \Delta$ ranged from 20 to 


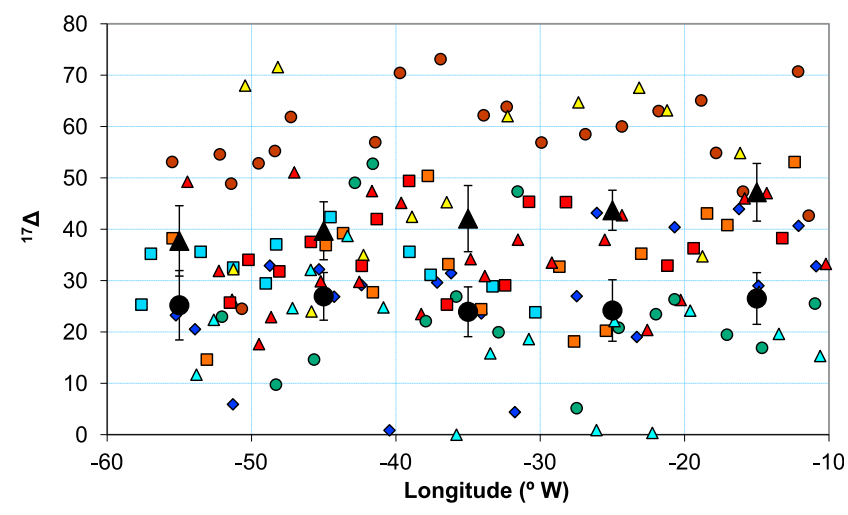

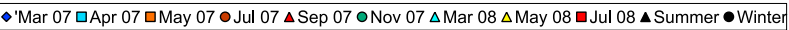

Figure 2. Measured ${ }^{17} \Delta$ (per meg) on nine Atlantic Companion cruises between March 2007 and June 2008 and the mean summer (May-Sep, triangles) and winter (NovMar, circles) values over $10^{\circ}$ longitude intervals (error bars represent \pm SEM at $95 \%$ confidence level).

57 per meg for nine cruises. A mean ${ }^{17} \Delta$ of $26 \pm 6$ per meg was measured on samples collected between 100 and $300 \mathrm{~m}$ $(\mathrm{n}=9)$ during the cruise in May 2008. During the summer when the surface mixed layer was well stratified and shallow (20-30 m), air-sea $\mathrm{O}_{2}$ equilibration time was short and mixed layer ${ }^{17} \Delta$ values are high (36-57 per meg), the likelihood of a significant entrainment bias in ${ }^{17} \Delta$-GOP is low. During the fall cruise in November 2007, when the mean MLD deepened to $60 \mathrm{~m}$ from $30 \mathrm{~m}$ in September and an entrainment bias would be expected, the mean mixed layer ${ }^{17} \Delta$ was $26 \pm 7$ per meg and the ${ }^{17} \Delta$-GOP estimate was the lowest of all nine cruises. Thus there was no evidence of significant entrainment biases in the ${ }^{17} \Delta$-GOP estimates presented here.

\section{Results}

\subsection{Longitudinal Trends in ${ }^{17} \Delta$ and GOP}

[31] Detecting spatial trends in ${ }^{17} \Delta$ on individual cruises is difficult because the analytical error in an individual ${ }^{17} \Delta$ measurement ( \pm 8 per meg) is similar to the average spatial variability of \pm 11 per meg ( $\pm 1 \mathrm{SD}$ ) on a typical cruise. The ability to detect spatial ${ }^{17} \Delta$ trends improves if we average the ${ }^{17} \Delta$ data from multiple cruises. For example, averaging the ${ }^{17} \Delta$ measurements from five cruises during the summer stratified period (May-Sep) yields is a slight westward ${ }^{17} \Delta$ decrease from $47 \pm 6$ to $38 \pm 7$ per meg between $10^{\circ} \mathrm{W}$ and $60^{\circ} \mathrm{W}$ (Figure 2). During the summer cruises, there was little westward change between $10^{\circ} \mathrm{W}$ and $50^{\circ} \mathrm{W}$ in $\mathrm{k}_{\mathrm{as}}(5.7 \pm$ 1.6 to $\left.5.4 \pm 1.2 \mathrm{~m} \mathrm{~d}^{-1}\right)$ and $\operatorname{MLD}(35 \pm 8$ to $32 \pm 13 \mathrm{~m})$, whereas west of $50^{\circ} \mathrm{W}$ there were significant decreases to $2.9 \pm 0.5 \mathrm{~m} \mathrm{~d}^{-1}$ and $21 \pm 5 \mathrm{~m}$, respectively. The westward trends in ${ }^{17} \Delta$ and $\mathrm{k}_{\mathrm{as}}$ yielded summer mean GOP rates in the mixed layer that decreased westward significantly from $283 \pm 80$ to $138 \pm 35 \mathrm{mmol} \mathrm{O}_{2} \mathrm{~m}^{-2} \mathrm{~d}^{-1}$ with most of the decrease occurring west of $50^{\circ} \mathrm{W}$ (Figure 3 ). There was no significant westward change in summer chlorophyll (mean of $0.5 \pm 0.1 \mathrm{mg} \mathrm{m}^{-3}$ ) and PAR (mean of $36 \pm 3 \mathrm{E} \mathrm{m}^{-2} \mathrm{~d}^{-1}$ ) between $10^{\circ} \mathrm{W}$ and $60^{\circ} \mathrm{W}$.

[32] During the winter cruises (Nov-Mar), there was no significant westward decrease in ${ }^{17} \Delta$ i.e., $27 \pm 5$ per meg at $10^{\circ}-20^{\circ} \mathrm{W}$ and $25 \pm 7$ per meg at $50^{\circ}-60^{\circ} \mathrm{W}$ (Figure 2). However, $\mathrm{k}_{\mathrm{as}}$ decreased westward from $5.4 \pm 1.2 \mathrm{~m} \mathrm{~d}^{-1}$ at $10-20^{\circ} \mathrm{W}$ to $3.6 \pm 0.4 \mathrm{~m} \mathrm{~d}^{-1}$ at $50-60^{\circ} \mathrm{W}$. There was a significant westward decrease in GOP from $136 \pm 56$ to $75 \pm 35 \mathrm{mmol} \mathrm{O}_{2} \mathrm{~m}^{-2} \mathrm{~d}^{-1}$ with most of the change occurring west of $50^{\circ} \mathrm{W}$ (Figure 3). Although the MLD decreased from $\sim 150$ to $40 \mathrm{~m}$ between $10^{\circ}$ and $60^{\circ} \mathrm{W}$ on the winter cruises, there were no significant westward decreases in chlorophyll (mean of $0.29 \pm 0.13 \mathrm{mg} \mathrm{m}^{-3}$ ) and PAR (mean of $13 \pm 2 \mathrm{E} \mathrm{m}^{-2} \mathrm{~d}^{-1}$ ) between $10^{\circ} \mathrm{W}$ and $60^{\circ} \mathrm{W}$.

[33] The proportion of photic layer GOP contained within the mixed layer depends on the MLD compared to photic layer depth. For the three winter cruises (Mar 07, Nov 07 and Mar 08), the mean ( $\pm 1 \mathrm{SD}$ ) basin-wide MLD (from ARGO floats) was $252 \pm 104 \mathrm{~m}, 57 \pm 17 \mathrm{~m}$, and $198 \pm 148$ $\mathrm{m}$, respectively. For the five summer cruises (May 07, Jul 07, Sep 07, May 08, Jun 08), the mean basin-wide MLD was $65 \pm 40 \mathrm{~m}, 21 \pm 8 \mathrm{~m}, 30 \pm 8 \mathrm{~m}, 26 \pm 6 \mathrm{~m}$ and $21 \pm 7 \mathrm{~m}$, respectively. During the development of a spring bloom near the NABE site over a three week period in May 1990, Bury et al. [2001] found that the depth of the $0.1 \%$ PAR level decreased from $30 \mathrm{~m}$ to $20 \mathrm{~m}$ as surface chlorophyll concentrations increased from $\sim 0.6$ to $3 \mathrm{mg} \mathrm{m}^{-3}$. Thus during the winter and spring bloom the GOP in the mixed layer should closely represent photic layer GOP. Under postbloom summer stratified conditions with lower surface chlorophyll concentrations and thus deeper photic layer the mixed layer GOP would underestimate photic layer GOP. During the cruise in July 2007, when the mean chlorophyll was $0.3 \mathrm{mg} \mathrm{m}^{-3}$ and MLD was $\sim 20 \mathrm{~m}$, the mixed layer GOP likely underestimated photic layer GOP.

\subsection{Annual Cycle of ${ }^{17} \Delta$ and GOP}

[34] A clear annual cycle in ${ }^{17} \Delta$ exists where the basinwide mean ${ }^{17} \Delta$ ranged from a minimum of $20 \pm 5$ per meg in March 2008 to a maximum of $57 \pm 5$ per meg in July 2007 (Figure 4). The basin-wide mean summer ${ }^{17} \Delta$ value of $42 \pm 6$ per meg was substantially higher than the mean winter ${ }^{17} \Delta$ value of $25 \pm 6$ per meg. There were significant

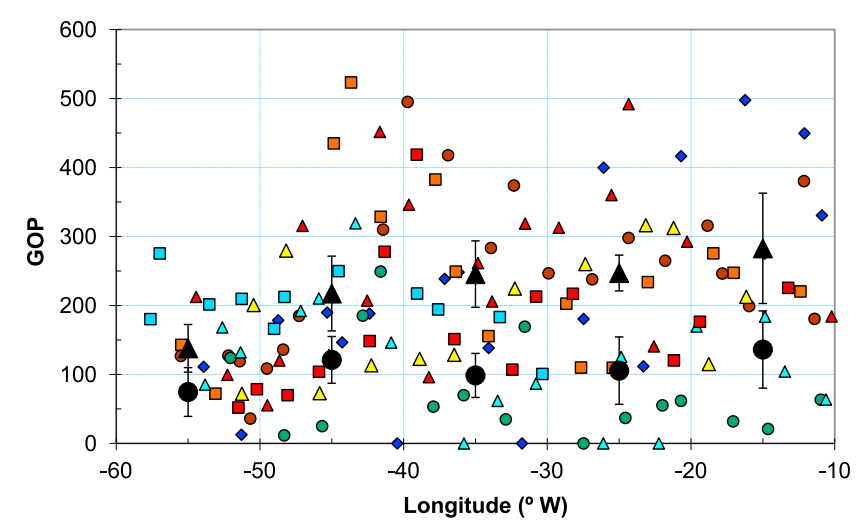

$\bullet$ 'Mar $07 \square$ Apr $07 \square$ May $07 \bullet$ Jul $07 \Delta$ Sep 07 @ Nov $07 \Delta$ Mar $08 \Delta$ May $08 \square$ Jul $08 \Delta$ Summer $\bullet$ Winter

Figure 3. Mixed layer gross oxygen production rate $\left({ }^{17} \Delta\right.$ GOP, mmol $\mathrm{O}_{2} \mathrm{~m}^{-2} \mathrm{~d}^{-1}$ ) estimates for nine Atlantic Companion cruises and the mean summer (May-Sep, triangles) and winter (Nov-Mar, circles) values over $10^{\circ}$ longitude intervals (error bars represent \pm SEM at $95 \%$ confidence level). 


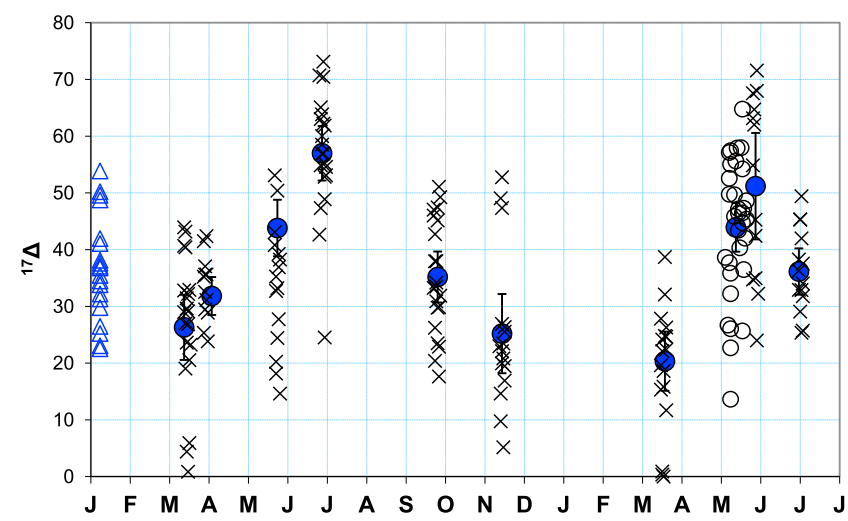

Figure 4. Mixed layer ${ }^{17} \Delta$ (per meg) measured on samples collected during nine Atlantic Companion cruises (crosses) between March 2007 and June 2008 and a research cruise near $\left(61^{\circ} \mathrm{N} 26^{\circ} \mathrm{W}\right)$ in May 2008 (open circles). Mean cruise-wide ${ }^{17} \Delta$ value (solid circles) where error bars represent \pm SEM at $95 \%$ confidence level. Variability of ${ }^{17} \Delta$ expected from \pm 8 per meg analytical error is plotted in January (triangles).

winter to summer changes in basin-wide mean MLD (97 \pm 28 to $33 \pm 9 \mathrm{~m}), \operatorname{PAR}\left(13 \pm 2\right.$ to $\left.36 \pm 3 \mathrm{E} \mathrm{m}^{-2} \mathrm{~d}^{-1}\right)$ and chlorophyll $\left(0.29 \pm 0.04\right.$ to $\left.0.51 \pm 0.14 \mathrm{mg} \mathrm{m}^{-3}\right)$.

[35] The mean basin-wide ${ }^{17} \Delta$-GOP during individual cruises varied by $3.5 \times$ from a maximum of $283 \pm 73 \mathrm{mmol}$ $\mathrm{O}_{2} \mathrm{~m}^{-2} \mathrm{~d}^{-1}$ in July 2007 to minimum of $80 \pm 35 \mathrm{mmol} \mathrm{O}_{2}$ $\mathrm{m}^{-2} \mathrm{~d}^{-1}$ in November 2007 (Figure 5). The seasonal cycle in basin-wide ${ }^{17} \Delta$-GOP primarily reflected the seasonal increase in ${ }^{17} \Delta$ rather than air-sea gas transfer rate, which were similar in winter (mean of $4.9 \pm 0.9 \mathrm{~m} \mathrm{~d}^{-1}$ ) and summer (mean of $4.7 \pm 0.8 \mathrm{~m} \mathrm{~d}^{-1}$ ).

\subsection{NCP and NCP/GOP}

[36] During the research cruise near Iceland $\left(\sim 61^{\circ} \mathrm{N}\right.$ $26^{\circ} \mathrm{W}$ ) in May 2008, ${ }^{17} \Delta$ and $\mathrm{O}_{2} / \mathrm{Ar}$ were measured at 22 stations on seawater samples collected from Niskin bottles. The mixed layer ${ }^{17} \Delta$ ranged from 14 to 65 per meg with a mean ${ }^{17} \Delta$ of $44 \pm 4$ per meg. The measured mixed layer $\mathrm{O}_{2} /$ Ar yielded a $\left(\mathrm{O}_{2} / \mathrm{Ar}\right)_{\text {sat }}$ range of 102.1 to $111.2 \%$ with a mean of $106.7 \pm 0.9 \%$. The $\mathrm{O}_{2}$ saturation state, calculated from $\mathrm{O}_{2}$ concentrations measured on water collected from the same Niskin as the $\mathrm{O}_{2} / \mathrm{Ar}$ samples, ranged from 102.2 to $112.5 \%$ with a mean of $106.2 \pm 1.0 \%(\mathrm{n}=21)$. There was a strong correlation between $\mathrm{O}_{2} / \mathrm{Ar}$ and $\mathrm{O}_{2}$ saturation $\left(\mathrm{r}^{2}=\right.$ 0.95). The mixed layer depths at the sampling stations ranged from 15 to $67 \mathrm{~m}$ with a mean of $39 \pm 18 \mathrm{~m}$ based on CTD measurements using a density increase criteria of $0.03 \mathrm{~kg} \mathrm{~m}^{-3}$. The mean nutrient concentrations were $9.3 \pm$ $1.5 \mu \mathrm{mol} \mathrm{kg}{ }^{-1}$ for nitrate, $0.44 \pm 0.23 \mu \mathrm{mol} \mathrm{kg}{ }^{-1}$ for phosphate and $1.14 \pm 0.53 \mu \mathrm{mol} \mathrm{kg}{ }^{-1}$ for silicate. The mean chlorophyll concentration was $1.8 \pm 1.1 \mathrm{mg} \mathrm{m}^{-3}$ in the mixed layer which was more than double the chlorophyll concentration of $0.7 \pm 0.3 \mathrm{mg} \mathrm{m}^{-3}$ estimated from SEAWIFS for this cruise. The mean air-sea gas transfer rate was $4.7 \pm 0.2 \mathrm{~m} \mathrm{~d}^{-1}$ estimated from QuikSCAT winds and Nightingale et al. [2000].

[37] The individual estimates of mixed layer NCP ranged from 31 to $148 \mathrm{mmol} \mathrm{O}_{2} \mathrm{~m}^{-2} \mathrm{~d}^{-1}$ with a mean of $87 \mathrm{mmol}$
$\mathrm{O}_{2} \mathrm{~m}^{-2} \mathrm{~d}^{-1}$. The mean mixed layer ${ }^{17} \Delta$-GOP was $245 \mathrm{mmol} \mathrm{O}_{2} \mathrm{~m}^{-2} \mathrm{~d}^{-1}$ and should be close to the photic layer GOP as the mean mixed layer depth $(39 \pm 16 \mathrm{~m})$ was equal to the mean depth $(37 \pm 5 \mathrm{~m})$ of the $1 \%$ light level over the sample collection interval during the cruise. The mean NCP/GOP was 0.36 (in $\mathrm{O}_{2}$ units).

\section{Discussion}

\subsection{Annual GOP and ${ }^{14}$ C-PP Cycle in Subpolar N. Atlantic}

[38] The mean summer (May-Sep) ${ }^{17} \Delta$-GOP of $226 \pm$ $48 \mathrm{mmol} \mathrm{O}_{2} \mathrm{~m}^{-2} \mathrm{~d}^{-1}$ was double the mean winter (NovMar) rate of $107 \pm 41 \mathrm{mmol} \mathrm{O}_{2} \mathrm{~m}^{-2} \mathrm{~d}^{-1}$, which yielded an annual mean rate of $166 \pm 45 \mathrm{mmol} \mathrm{O}_{2} \mathrm{~m}^{-2} \mathrm{~d}^{-1}$. The summer mixed layer ${ }^{17} \Delta$-GOP rate compares well with the GOP rate of $206 \mathrm{mmol} \mathrm{O}_{2} \mathrm{~m}^{-2} \mathrm{~d}^{-1}$ measured by Bender et al. [1992] using ${ }^{18} \mathrm{O}$-labeled water in bottle incubations during NABE (May 1989).

[39] Most previous PP estimates in the subpolar $\mathrm{N}$. Atlantic are based on ${ }^{14} \mathrm{C}-\mathrm{PP}$ measurements. To compare to these rates, the current ${ }^{17} \Delta$-GOP estimates are converted to an equivalent ${ }^{14} \mathrm{C}$-PP rate $\left({ }^{14} \mathrm{C}-\mathrm{PP}_{\text {eqv }}\right)$ assuming a $\mathrm{GOP} /{ }^{14} \mathrm{C}$-PP of $2.7 \pm 0.2$ measured by concurrent $24 \mathrm{~h}{ }^{18} \mathrm{O}$ and ${ }^{14} \mathrm{C}$ bottle incubations during JGOFS [e.g., Bender et al., 1999; Laws et al., 2000; Marra, 2002], as discussed above. The mean ${ }^{14} \mathrm{C}-\mathrm{PP}_{\text {eqv }}$ for individual cruises varied by $\sim 3.5 \times$ from a maximum of $1259 \pm 321 \mathrm{mg} \mathrm{C} \mathrm{m}^{-2} \mathrm{~d}^{-1}$ (Jul 07 ) to minimum of $356 \pm 157 \mathrm{mg} \mathrm{C} \mathrm{m}^{-2} \mathrm{~d}^{-1}$ (Nov 07) (Figure 6). Mean summer ${ }^{14} \mathrm{C}_{-} \mathrm{PP}_{\text {eqv }}$ of $1005 \pm 216 \mathrm{mg} \mathrm{C}$ $\mathrm{m}^{-2} \mathrm{~d}^{-1}$ was double the mean winter rate of $476 \pm 183 \mathrm{mg}$ $\mathrm{C} \mathrm{m}^{-2} \mathrm{~d}^{-1}$, which yielded an annual mean of $741 \pm 200 \mathrm{mg}$ $\mathrm{C} \mathrm{m}{ }^{-2} \mathrm{~d}^{-1}$.

[40] The ${ }^{14} \mathrm{C}-\mathrm{PP}_{\text {eqv }}$ estimates are within the range previously reported in the subpolar N. Atlantic (Table 1). During NABE (May 1989-1990), four separate productivity studies measured ${ }^{14} \mathrm{C}-\mathrm{PP}$ rates of $580 \pm 140,840 \pm 350,1080 \pm$ 153 and $1260 \pm 198 \mathrm{mg} \mathrm{C} \mathrm{m}^{-2} \mathrm{~d}^{-1}$. During POMME,

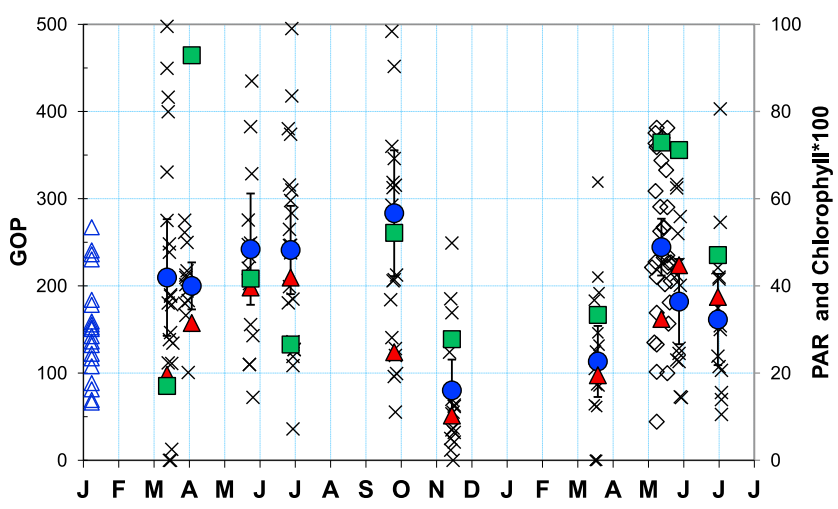

Figure 5. Mixed layer ${ }^{17} \Delta$-GOP (crosses, mmol $\mathrm{O}_{2} \mathrm{~m}^{-2}$ $\left.\mathrm{d}^{-1}\right)$, PAR (triangles, $\left.\mathrm{E} \mathrm{m}^{-2} \mathrm{~d}^{-1}\right)$ and chlorophyll $(* 100$, squares, $\mathrm{mg} \mathrm{m}^{-3}$ ) for each Atlantic Companion cruise (March 2007 to June 2008) and a research cruise (diamonds) in May 2008. Mean cruise-wide ${ }^{17} \Delta$-GOP values (circles) with error bars representing SEM at 95\% confidence level. Variability of ${ }^{17} \Delta$-GOP expected from a \pm 8 per meg analytical error in ${ }^{17} \Delta$ (with constant $\mathrm{k}_{\mathrm{g}}$ ) plotted in January (triangles). 


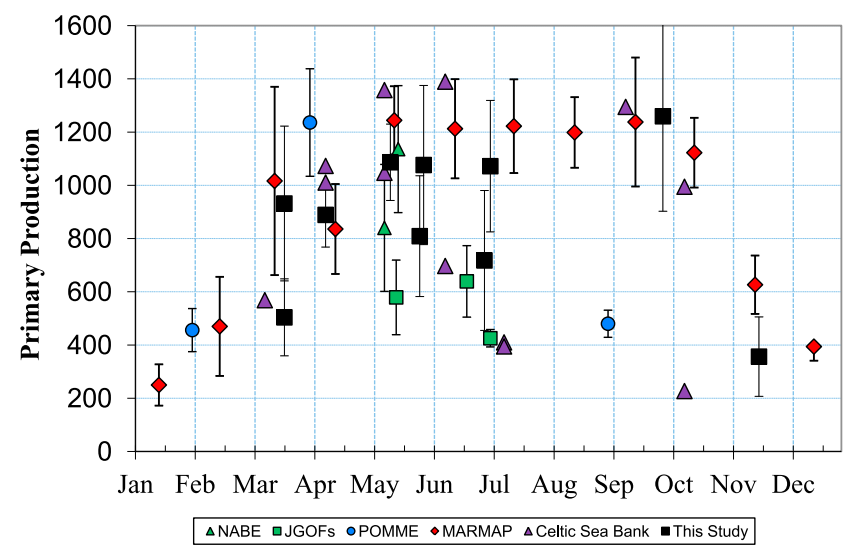

Figure 6. ${ }^{14} \mathrm{C}-\mathrm{PP}\left(\mathrm{mg} \mathrm{C} \mathrm{m}{ }^{-2} \mathrm{~d}^{-1}\right)$ estimated from ${ }^{17} \Delta$ GOP rates $\left({ }^{14} \mathrm{C}-\mathrm{PP}\right.$ eqv, black squares) between March 2007 and June 2008, measured during the NABE (triangles), JGOFS (green squares) and POMME (circles) programs (1989-90 and 2001) and mean monthly rates measured during MARMAP (1978-1982) in Gulf of Maine and Georges Bank (diamonds). Error bars represent \pm SEM at $95 \%$ confidence level.

${ }^{14} \mathrm{C}$-PP rates (used ${ }^{13} \mathrm{C}$ label) of 456, 1236 and $420 \mathrm{mg} \mathrm{C}$ $\mathrm{m}^{-2} \mathrm{~d}^{-1}$ were measured in Jan, March and August 2001, respectively.

[41] There are few ${ }^{14} \mathrm{C}-\mathrm{PP}$ data sets with sufficient temporal coverage to determine the annual cycle in PP in the subpolar North Atlantic and with which to compare the current ${ }^{14} \mathrm{C}-\mathrm{PP}{ }_{\text {eqv }}$ estimates. By far the most detailed ${ }^{14} \mathrm{C}$-PP data set in the region is from MARMAP where $\sim 700{ }^{14} \mathrm{C}-\mathrm{PP}$ depth profiles were measured (1978-82) in Georges Bank and the Gulf of Maine. Although the MARMAP study site is coastal and not directly comparable to the open subpolar N. Atlantic, the annual cycle in ${ }^{14} \mathrm{C}$-PP from MARMAP provides one benchmark with which to evaluate the observed seasonality in the ${ }^{14} \mathrm{C}-\mathrm{PP}_{\text {eqv }}$ rates measured during the nine Atlantic Companion cruises (Figure 6). During MARMAP, the mean ${ }^{14} \mathrm{C}-\mathrm{PP}$ rate in summer (Jun-Aug) was $\sim 3.3 \times$ the rate in winter (Dec-Feb) (Table 1). The ${ }^{14} \mathrm{C}-\mathrm{PP}_{\text {eqv }}$ rates were $\sim 20 \%$ lower than ${ }^{14} \mathrm{C}$-PP measured during MARMAP with less seasonality (summer/winter $=2.5$ ). There was a clear ${ }^{14} \mathrm{C}$-PP peak in March during MARMAP that is not observed in ${ }^{14} \mathrm{C}-\mathrm{PP}_{\text {eqv }}$ (Figure 6). However, these differences may in part result from the limited number of Atlantic Companion cruises especially in winter and regional differences between the two data sets. Potentially, an important issue is how much the productivity in the subpolar $\mathrm{N}$. Atlantic drops off after the spring bloom ends. The MARMAP ${ }^{14} \mathrm{C}$-PP data indicate high bloom-type PP rates extend through the end of summer (Figure 6). Similarly, an ecosystem model by Moore et al. [2001] predicts high PP rates $\left(\sim 900 \mathrm{mg} \mathrm{C} \mathrm{m}^{-2} \mathrm{~d}^{-1}\right)$ at the NABE site continues until September. The ${ }^{14} \mathrm{C}-\mathrm{PP}$ eqv estimates suggest that high PP continues throughout the summer (Figure 7), but better temporal resolution is needed to fully address this issue.

\subsection{Comparison With Satellite PP Estimates}

[42] The ${ }^{14} \mathrm{C}-\mathrm{PP}_{\text {eqv }}$ estimates were compared to PP estimated from two satellite algorithms (VGPM and CbPM) as described by Behrenfeld and Falkowski [1997] and
Westberry et al. [2008], respectively. The satellite PP estimate represents a 30-day mean value for $\mathrm{a} \sim 1^{\circ} \times 1^{\circ}$ grid around each sampling location along the cruise track. Notably, the time integration scales of the ${ }^{14} \mathrm{C}-\mathrm{PP}_{\text {eqv }}$ and satellite PP estimates are similar ( $\sim$ weeks) during summer, which is a significant improvement over the time scale mismatch between satellite and ${ }^{14} \mathrm{C}$ incubation-based estimates of PP. The mean basin-wide ${ }^{14} \mathrm{C}-\mathrm{PP}_{\text {eqv }}$ for each cruise is compared to the mean PP rates along the entire cruise track estimated by VGPM and CbPM, rather than comparing individual estimates of ${ }^{14} \mathrm{C}-\mathrm{PP}_{\text {eqv }}$ because of the large uncertainty in individual ${ }^{17} \Delta$-GOP estimates, as discussed above. All three PP estimates showed a clear seasonality (Figure 7). The mean ${ }^{14} \mathrm{C}_{-} \mathrm{PP}_{\text {eqv }}$ in summer at $1005 \pm$ $216 \mathrm{mg} \mathrm{C} \mathrm{m}^{-2} \mathrm{~d}^{-1}$ agreed well (5\%) with the mean summer VGPM-PP of $964 \pm 121 \mathrm{mg} \mathrm{C} \mathrm{m}^{-2} \mathrm{~d}^{-1}$ and was $\sim 65 \%$ higher than the mean CbPM-PP estimate of $603 \pm 117 \mathrm{mg} \mathrm{C}$ $\mathrm{m}^{-2} \mathrm{~d}^{-1}$. Similarly, the mean winter ${ }^{14} \mathrm{C}_{-} \mathrm{PP}_{\text {eqv }}$ at $476 \pm$ $183 \mathrm{mg} \mathrm{C} \mathrm{m}^{-2} \mathrm{~d}^{-1}$ was within $\sim 15 \%$ of the VGPM-PP at $412 \pm 33 \mathrm{mg} \mathrm{C} \mathrm{m}^{-2} \mathrm{~d}^{-1}$ and $\sim 50 \%$ higher than the CbPM$\mathrm{PP}$ at $310 \pm 73 \mathrm{mg} \mathrm{C} \mathrm{m}^{-2} \mathrm{~d}^{-1}$. The closer agreement between ${ }^{14} \mathrm{C}_{-P P}$ eqv and VGPM-PP may in part be their common dependence on ${ }^{14} \mathrm{C}$-PP data. Furthermore, the VGPM $\mathrm{PP}$ algorithm relies heavily on the MARMAP ${ }^{14} \mathrm{C}-\mathrm{PP}$ data set to calibrate the light dependence of PP [Behrenfeld and Falkowski, 1997], whereas CbPM-PP is independent of ${ }^{14} \mathrm{C}-\mathrm{PP}$ [Westberry et al., 2008]. The observation that CbPM-PP ranges from $63 \%$ (winter) to $75 \%$ (summer) of VGPM along the Atlantic Companion cruise track agrees with the results of Westberry et al. [2008], who found that globally CbPM-PP was 67\% of VGPM-PP at high latitudes. [43] Previously, ${ }^{14} \mathrm{C}-\mathrm{PP}_{\text {eqv }}$ estimates derived from ${ }^{17} \Delta$ GOP rates in the subtropical and equatorial Pacific Ocean Southern Ocean were found to be 1.5-2x VGPM-PP and CbPM-PP estimates [Juranek and Quay, 2010]. Similarly, Reuer et al. [2007] found that ${ }^{14} \mathrm{C}^{\mathrm{PP}}{ }_{\text {eqv }}$ estimated from ${ }^{17} \Delta$-GOP in the Southern Ocean were $\sim 2 \times$ VGPM-PP estimates. The result that ${ }^{14} \mathrm{C}-\mathrm{PP}$ eqv is $1.6 \times$ CbPM-PP in the

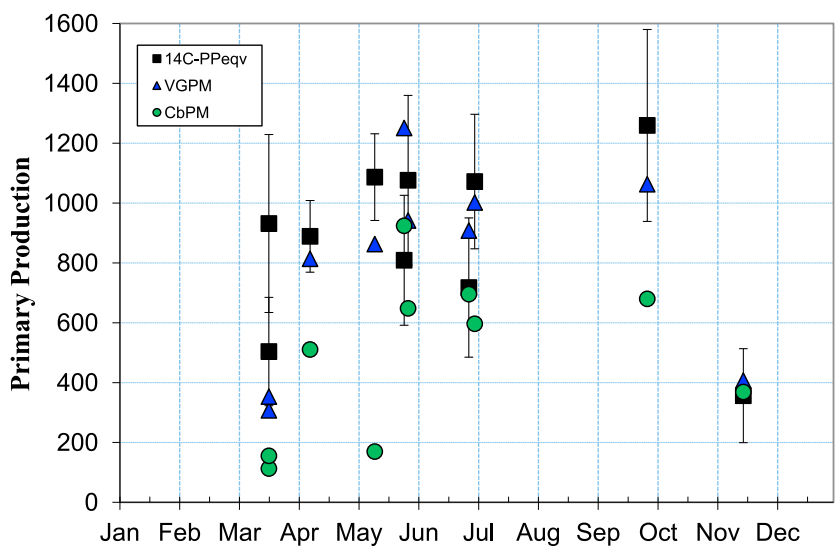

Figure 7. The mean basin-wide of ${ }^{14} \mathrm{C}-\mathrm{PP}_{\text {eqv }}\left(\mathrm{mg} \mathrm{C} \mathrm{m}^{-2}\right.$ $\mathrm{d}^{-1}$, squares) estimated from ${ }^{17} \Delta$-GOP for each cruise compared to the concurrent primary production rates estimated using satellite algorithms VGPM (triangles) [Behrenfeld and Falkowski, 1997] and CbPM (circles) [Westberry et $a l ., 2008]$. The error bars represent \pm SEM at $95 \%$ confidence level. 


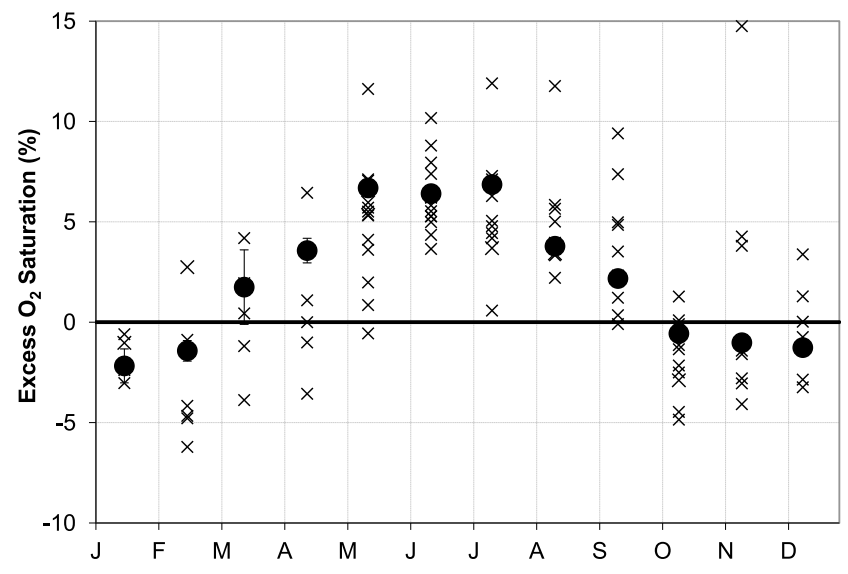

Figure 8. The monthly average $\mathrm{O}_{2}$ saturation excess (\%, where saturation with air is $0 \%$ ) in surface layer of the subpo$\operatorname{lar} \mathrm{N}$. Atlantic $\left(40^{\circ}-65^{\circ} \mathrm{N}, 10^{\circ}-60^{\circ} \mathrm{W}\right)$ for each year between 1991 and 2005 (crosses) based on $\sim 90$ cruises and $\sim 5000$ measurements during the CARINA program [Stendardo et al., 2009]. The mean monthly average for the 15 year interval (circles) with error bars that represent the SEM at 95\% confidence level (usually within the symbol size).

present study is consistent with these previous studies, whereas the good agreement between ${ }^{14} \mathrm{C}-\mathrm{PP}$ eqv and VGPMPP is surprising, but possibly due to VGPM's dependence on MARMAP ${ }^{14} \mathrm{C}$-PP data for calibration. One can expect substantial regional variability in comparisons between ${ }^{14} \mathrm{C}$ $\mathrm{PP}_{\text {eqv }}$ and satellite $\mathrm{PP}$ as a result of the factor of two uncertainty in the satellite-based PP estimates [Campbell et al., $2002]$ and the significant uncertainty $(\sim 45 \%)$ in ${ }^{17} \Delta$-GOP rates and the $\mathrm{GOP} /{ }^{14} \mathrm{C}$-PP scaling factor.

\subsection{Net Community Production}

\subsubsection{Spring Bloom Conditions}

[44] The rates of NCP were estimated using the $\mathrm{O}_{2} / \mathrm{Ar}$ measurements during a research cruise near Iceland $\left(61^{\circ} \mathrm{N}\right.$ $\left.26^{\circ} \mathrm{W}\right)$ in May 2008 under bloom conditions. The mean $\mathrm{O}_{2} /$ Ar supersaturation of $6.7 \pm 0.8 \%$ for May 5-21 agrees well with the mean $\mathrm{O}_{2}$ saturation of $6.2 \pm 1 \%$ measured during the cruise indicating that the $\mathrm{O}_{2}$ supersaturation is biologically produced. In comparison, Bender et al. [1992] measured a mean $\mathrm{O}_{2}$ supersaturation of 6\% during May 1989 at the NABE site and a long-term (1991 to 2005) mean monthly $\mathrm{O}_{2}$ supersaturation of $6.7 \pm 0.3 \%(\mathrm{n}=1182)$ was measured during May between $40^{\circ}$ and $65^{\circ} \mathrm{N}$ during CARINA cruises [Stendardo et al., 2009]. A mean NCP rate of $87 \pm 22 \mathrm{mmol} \mathrm{O}_{2} \mathrm{~m}^{-2} \mathrm{~d}^{-1}$ for the mixed layer (mean $\mathrm{MLD}=39 \pm 6 \mathrm{~m}$ ) is calculated (using equation (3)) from the mean $\mathrm{O}_{2} / \mathrm{Ar}$ saturation, $\mathrm{k}_{\mathrm{g}}$ of $4.7 \mathrm{~m} \mathrm{~d}^{-1}$ and $\mathrm{O}_{2 \text { sat }}$ of $280 \mu \mathrm{mol} \mathrm{kg} \mathrm{kg}^{-1}$.

[45] The $\mathrm{O}_{2} /$ Ar-based NCP estimate yields an OC export rate of $62 \pm 9 \mathrm{mmol} \mathrm{C} \mathrm{m} \mathrm{C}^{-2} \mathrm{~d}^{-1}$ assuming a PQ of 1.4 , as discussed above, which falls within the range of OC export rates during this cruise estimated by three independent methods. Alkire et al. [2012] estimated an NCP rate of $115 \mathrm{mmol} \mathrm{C} \mathrm{m}^{-2} \mathrm{~d}^{-1}$ integrated to $\sim 60 \mathrm{~m}$ during the peak bloom interval (May 6-13) based on nitrate, $\mathrm{O}_{2}$ and $\mathrm{POC}$ budgets measured using a profiling Lagrangian float following a bloom patch. Martin et al. [2011] estimated a POC export rate of $30-50 \mathrm{mmol} \mathrm{C} \mathrm{m} \mathrm{m}^{-2} \mathrm{~d}^{-1}$ at $100 \mathrm{~m}$ based on a ${ }^{234}$ Th budget. Briggs et al. [2011] estimated a POC flux of $57 \mathrm{mmol} \mathrm{C} \mathrm{m} \mathrm{d}^{-2}$ at $60 \mathrm{~m}$ based on aggregate sinking rates derived from depth profiles of fluorescence and backscatter measured using a glider. Likewise, the $\mathrm{O}_{2} / \mathrm{Ar}$-based NCP estimate of $62 \pm 16 \mathrm{mmol} \mathrm{C} \mathrm{m} \mathrm{C}^{-2} \mathrm{~d}^{-1}$ in May 2008 falls in the middle of the $30-90 \mathrm{mmol} \mathrm{C} \mathrm{m}^{-2} \mathrm{~d}^{-1}$ range estimated using DIC, POC, nutrient, $\mathrm{O}_{2}$ and ${ }^{234} \mathrm{Th}$ budgets in May 1989 during NABE and, furthermore, agrees well an NCP rate of $70 \mathrm{mmol} \mathrm{C} \mathrm{m}^{-2} \mathrm{~d}^{-1}$ during Mar-May 2004 at a site near NABE estimated by Körtzinger et al. [2008] based on continuous mooring measurements of $\mathrm{pCO}_{2}$ in the surface mixed layer and a DIC budget (Table 2).

[46] The $\mathrm{O}_{2} /$ Ar-based NCP estimate of $87 \pm 12 \mathrm{mmol} \mathrm{O}_{2}$ $\mathrm{m}^{-2} \mathrm{~d}^{-1}$ during bloom conditions in May 2008 in the subpolar $\mathrm{N}$ Atlantic was $\sim 10 \times$ higher than the $\mathrm{O}_{2} /$ Ar-based NCP rates of 6 to $12 \mathrm{mmol} \mathrm{O}_{2} \mathrm{~m}^{-2} \mathrm{~d}^{-1}$ estimated at the BATS time series station in the subtropical N. Atlantic and even exceeded the daily $\mathrm{O}_{2} / \mathrm{Ar}$-based NCP rates of $22-50$ and $42 \pm 14 \mathrm{mmol} \mathrm{O}_{2} \mathrm{~m}^{-2} \mathrm{~d}^{-1}$ estimated for the Southern Ocean and off the coast of southern California, respectively.

\subsubsection{Annual Rate}

[47] The daily rate of NCP (OC export) in the subpolar N. Atlantic integrated over the annual cycle will be significantly lower than the daily rate measured during spring bloom conditions for two reasons. First, PP is higher during the summer by $\sim 2-3 \times$ compared to winter (Figure 6 ). Second, the effective OC export rate depends on the depth of the winter mixed layer because respiration below the photic layer reduces $\mathrm{OC}$ export. Using continuous nitrate and $\mathrm{pCO}_{2}$ measurements at a mooring site near NABE in the subpolar N. Atlantic, Körtzinger et al. [2008] estimated that $40 \%$ of the OC exported from the photic layer during the stratified summer season was respired to $\mathrm{CO}_{2}$ within the depth of the winter mixed layer $(\sim 240 \mathrm{~m})$ and potentially released back to the atmosphere during winter. Körtzinger et al. estimated an annual OC export rate of $3.6 \pm 2.8 \mathrm{~mol} \mathrm{C} \mathrm{m}^{-2} \mathrm{yr}^{-1}(10 \pm$ $8 \mathrm{mmol} \mathrm{C} \mathrm{m}^{-2} \mathrm{~d}^{-1}$ ) that on a daily basis was $\sim 7 \times$ less than the export rate from the mixed layer during bloom conditions and similar to the estimated annual OC export rate of 3-4 mol C m${ }^{-2} \mathrm{yr}^{-1}$ at BATS [Gruber et al., 2002; Jenkins and Doney, 2003]. Thus over an annual cycle, the OC export rate depends significantly on both biological and physical characteristics of the region. In regions like the subpolar N. Atlantic, where there are large seasonal changes in biological productivity and mixed layer depth, sufficient measurements of OC export over the year are needed to yield accurate annual rates of $\mathrm{OC}$ export.

[48] The annual rate of OC export rate on a basin-wide scale in the subpolar N. Atlantic can be estimated from surface layer $\mathrm{O}_{2}$ data compiled during the CARINA program across the subpolar N. Atlantic $\left(40^{\circ} \mathrm{N}-65^{\circ} \mathrm{N}, 10^{\circ} \mathrm{W}-60^{\circ} \mathrm{W}\right)$ from $\sim 90$ cruises between 1991 and 2005 that yielded a total of $\sim 5000$ surface $\mathrm{O}_{2}$ measurements [Stendardo et al., 2009]. Monthly average surface $\mathrm{O}_{2}$ saturation levels were calculated and showed a clear annual cycle from $98 \%$ in winter to $107 \%$ in summer (Figure 8). Between March and September, the surface layer is supersaturated in $\mathrm{O}_{2}$ and between October and February the surface layer is undersaturated. In comparison, the $\mathrm{O}_{2}$ and $\mathrm{O}_{2} / \mathrm{Ar}$ saturation levels measured during the May 2008 Knorr cruise were $106.7 \pm 0.9 \%$ and $106.3 \pm 1.0 \%$, respectively, which agreed well with the 
climatology represented by the CARINA data set where the mean $\mathrm{O}_{2}$ saturation was $106.7 \pm 0.3 \%$ in May.

[49] An estimate of the annual NCP rate for the subpolar N. Atlantic based on the CARINA $\mathrm{O}_{2}$ data set was obtained by assuming that the 15 year data set represents average conditions with no long-term surface $\mathrm{O}_{2}$ time rate of change and negligible net horizontal or vertical transport of $\mathrm{O}_{2}$ out of the region. Under these conditions the annual average $\mathrm{NCP}$ equals the net annual air-sea $\mathrm{O}_{2}$ flux. Average monthly wind speeds for the region during the measurement period (1991-2005) were determined from the NCEP climatology and monthly mean $\mathrm{k}_{\mathrm{g}}$ values estimated from Nightingale et al. [2000], as discussed above. An annual mean NCP rate of $11 \pm 10 \mathrm{mmol} \mathrm{O}_{2} \mathrm{~m}^{-2} \mathrm{~d}^{-1}$ was determined by summing the monthly air-sea $\mathrm{O}_{2}$ flux which in turn was calculated from the monthly $\mathrm{O}_{2}$ saturation state and $\mathrm{k}_{\mathrm{g}}$ estimates. The uncertainty represents the combined errors in $\mathrm{k}_{\mathrm{g}}$ $( \pm 25 \%)$ and the spatial and temporal variability of the monthly $\mathrm{O}_{2}$ saturation level.

[50] A comparison of annual and spring/summer integrated NCP rates (130 and $232 \mathrm{mmol} \mathrm{O}_{2} \mathrm{~m}^{-2}$, respectively) estimated from the monthly CARINA $\mathrm{O}_{2}$ data indicates that $\sim 45 \%$ of the organic material exported from the mixed layer during spring/summer (Mar-Sep) is respired to $\mathrm{CO}_{2}$ within the depth of the winter mixed layer during the year. This result is similar to the observations of Körtzinger et al. [2008] at the PAP site, who found that $\sim 40 \%$ of summer NCP was consumed by respiration within the winter MLD and produced $\mathrm{CO}_{2}$ that ultimately was released back to the atmosphere.

[51] The estimated annual NCP rate based on basin-wide CARINA $\mathrm{O}_{2}$ data at $2.8 \pm 2.7 \mathrm{~mol} \mathrm{C} \mathrm{m}^{-2} \mathrm{yr}^{-1}(8 \pm 7 \mathrm{mmol}$ $\mathrm{C} \mathrm{m}^{-2} \mathrm{~d}^{-1}$ ) is similar to the annual rate of $3.6 \pm 2.8 \mathrm{~mol} \mathrm{C}$ $\mathrm{m}^{-2} \mathrm{yr}^{-1}$ estimated by Körtzinger et al. [2008] at the PAP site and, furthermore, to the NCP rate of 3-4 mol C m${ }^{-2}$ $\mathrm{yr}^{-1}$ estimated at BATS in the subtropical N. Atlantic. The latter comparison underscores the importance of winter MLD on the effective OC export.

\subsection{Efficiency of Biological Pump}

[52] The ratio of NCP/GOP (i.e., e-ratio) provides one measure of the efficiency of the biological pump, i.e., the portion of photosynthetic $\mathrm{O}_{2}$ production that is not consumed by community respiration and, in organic carbon equivalents, is available for export or transfer up the food chain. An estimate of $\mathrm{NCP} / \mathrm{GOP}$ resulted from combined $\mathrm{O}_{2} /$ $\mathrm{Ar}$ and ${ }^{17} \Delta$ measurements (equation (4)) and yielded a mean of $0.35 \pm 0.07$ for the 22 stations sampled during the research cruise off Iceland in May 2008. Previously, Bender et al.'s [1992] estimates of NCP $\left(119 \mathrm{mmol} \mathrm{O}_{2} \mathrm{~m}^{-2} \mathrm{~d}^{-1}\right)$ based on a dissolved $\mathrm{O}_{2}$ budget and GOP $\left(206 \mathrm{mmol} \mathrm{O}_{2}\right.$ $\mathrm{m}^{-2} \mathrm{~d}^{-1}$ ) based on labeled ${ }^{18} \mathrm{O}$ bottle incubations yield a NCP/GPP of 0.58 during NABE.

[53] The e-ratio can be expressed in carbon units with ${ }^{14} \mathrm{C}_{-\mathrm{PP}}$ eqv in the denominator by multiplying the NCP/GOP (in $\mathrm{O}_{2}$ units) by $\sim 2$ (i.e., divide the NCP in $\mathrm{mmol} \mathrm{O}_{2} \mathrm{~m}^{-2} \mathrm{~d}^{-1}$ by 1.4 and divide the GOP in $\mathrm{mmol} \mathrm{O}_{2} \mathrm{~m}^{-2} \mathrm{~d}^{-1}$ by 2.7). Thus a mean e-ratio $\left(\mathrm{NCP} /{ }^{14} \mathrm{C}-\mathrm{PP}_{\text {eqv }}\right)$ of $0.70 \pm 0.14$ in carbon units resulted from the $\mathrm{O}_{2} / \mathrm{Ar}$ and ${ }^{17} \Delta$ based estimate of $\mathrm{NCP} / \mathrm{GOP}$ of $0.35 \pm 0.07$ during spring bloom conditions in May 2008. Previously, e-ratio estimates ranged from 0.5 to
1.0 during NABE and JGOFS under spring bloom conditions and $\sim 0.3$ at other times of the year during POMME in the subpolar N. Atlantic (Table 3). The NCP/GPP of $0.35 \pm$ 0.07 estimated in May 2008 is $2-6 \times$ the NCP/GPP range of 0.06 to 0.19 (mean $0.13 \pm 0.05$ ) estimated from previous $\mathrm{O}_{2} /$ $\mathrm{Ar}$ and ${ }^{17} \Delta$ measurement programs in the subtropical, equatorial, coastal and southern ocean (Table 3). At face value these results imply that during the spring bloom in the subpolar N. Atlantic, the fraction of PP exported (or harvested) as $\mathrm{OC}$ is at least twice as great as in most other oceanic regions.

[54] Based on observations during NABE, a high e-ratio in this region during bloom conditions may be a result of rapid biological fixation of $\mathrm{CO}_{2}$ by diatoms (which comprised up to $90 \%$ of phytoplankton carbon during early stages of bloom) coupled with low mesozooplankton grazing rates ( $<5 \%$ of PP), as discussed by Lochte et al. [1993]. However, the depth of winter mixed layer is an important factor affecting the efficiency of organic carbon export integrated over the annual cycle as pointed out by Oschlies and Kahler [2004] and Körtzinger et al. [2008] and discussed above. The deeper the winter mixed layer, the less organic carbon escapes respiration and is sequestered from air-sea $\mathrm{CO}_{2}$ exchange. To illustrate this effect, we divided the annual average NCP of $11 \pm 10 \mathrm{mmol} \mathrm{O}_{2} \mathrm{~m}^{-2} \mathrm{~d}^{-1}$ estimated from the CARINA $\mathrm{O}_{2}$ data and by the annual average GOP of $167 \pm 45 \mathrm{mmol} \mathrm{O}_{2} \mathrm{~m}^{-2} \mathrm{~d}^{-1}$ estimated from the ${ }^{17} \Delta$ measurements during the nine container ship cruises to yield a $\mathrm{NCP} / \mathrm{GOP}$ of $0.07 \pm 0.06$. This $\mathrm{NCP} / \mathrm{GOP}$ estimate is $5 \times$ lower than the estimate of $0.35 \pm 0.05$ during bloom conditions in May 2008 and at the low end of the 0.06 to 0.19 range observed at other ocean sites (Table 3 ). Thus, despite the high efficiency of OC export during the spring bloom much of this efficiency is offset by respiration of organic matter in the depth region between the photic layer and winter MLD.

\section{Summary and Conclusions}

[55] The utility of combining the ${ }^{17} \Delta$ measurements with a container ship sampling platform to determine basinwide primary productivity rates in the subpolar N. Atlantic over an annual cycle was demonstrated. Rates of GOP and NCP and the export efficiency (NCP/GOP) in spring bloom conditions were estimated based on ${ }^{17} \Delta$ and $\mathrm{O}_{2} / \mathrm{Ar}$ measurements during a cruise near Iceland in May 2008. Annual NCP rates for this region were estimated from 15 year compilation of surface $\mathrm{O}_{2}$ measurements during the CARINA program.

[56] Specifically, we found the following:

[57] 1. The summer mixed layer ${ }^{17} \Delta$-GOP rate at $226 \pm$ $48 \mathrm{mmol} \mathrm{O}_{2} \mathrm{~m}^{-2} \mathrm{~d}^{-1}$ is more than double the winter rate of $107 \pm 41 \mathrm{mmol} \mathrm{O}_{2} \mathrm{~m}^{-2} \mathrm{~d}^{-1}$ and together yield an annual rate of $167 \pm 45 \mathrm{mmol} \mathrm{O}_{2} \mathrm{~m}^{-2} \mathrm{~d}^{-1}$.

[58] 2. ${ }^{14} \mathrm{C}-\mathrm{PP}_{\text {eqv }}$ during summer cruises agreed well with ${ }^{14} \mathrm{C}$-PP rates measured previously under bloom conditions during the NABE and suggest high $\mathrm{PP}$ rates continue throughout summer. The $2-3 \times$ seasonality in ${ }^{14} \mathrm{C}-\mathrm{PP}_{\text {eqv }}$ derived from ${ }^{17} \Delta$-GOP estimates generally agrees well with climatological annual cycle in ${ }^{14} \mathrm{C}$-PP measured in the Gulf of Maine during MARMAP. 
[59] 3. The ${ }^{14} \mathrm{C}-\mathrm{PP}_{\text {eqv }}$ estimates agree well with satellite based PP estimates by the VGPM algorithm but are $\sim 60 \%$ higher than rates estimated by the CbPM algorithm.

[60] 4. The ${ }^{17} \Delta$-GOP method had difficulty detecting spatial variations in GOP during individual cruises because the analytical error in the ${ }^{17} \Delta$ measurement is of the same magnitude as the spatial variability in ${ }^{17} \Delta$.

[61] 5. Averaged over six summer cruises, the mean mixed layer ${ }^{17} \Delta$-GOP in the eastern edge of the basin at $283 \pm$ $80 \mathrm{mmol} \mathrm{O}_{2} \mathrm{~m}^{-2} \mathrm{~d}^{-1}$ was double the ${ }^{17} \Delta$-GOP in the western edge of the basin at $138 \pm 35 \mathrm{mmol} \mathrm{O}_{2} \mathrm{~m}^{-2} \mathrm{~d}^{-1}$.

[62] 6. The mean NCP rate of $62 \pm 9 \mathrm{mmol} \mathrm{C} \mathrm{m}^{-2} \mathrm{~d}^{-1}$ estimated from $\mathrm{O}_{2} / \mathrm{Ar}$ saturation levels measured during spring bloom conditions in May 2008 was within the range of $\sim 30$ to $115 \mathrm{mmol} \mathrm{C} \mathrm{m}^{-2} \mathrm{~d}^{-1}$ estimated by three independent methods during this cruise and previously during NABE.

[63] 7. An annual mean $\mathrm{OC}$ export rate of $2.8 \pm 2.7 \mathrm{~mol} \mathrm{C}$ $\mathrm{m}^{-2} \mathrm{yr}^{-1}$ for the subpolar N. Atlantic was estimated from 15 years of surface $\mathrm{O}_{2}$ measurements during CARINA program and implies that $\sim 45 \%$ of the organic material exported from the mixed layer during summer is respired to $\mathrm{CO}_{2}$ within the depth of the winter mixed layer. This annual mean $\mathrm{OC}$ export rate is similar to estimated export rate in the subtropical N. Atlantic.

[64] 8. A mixed layer NCP/GOP of $0.35 \pm 0.05$ estimated from $\mathrm{O}_{2} / \mathrm{Ar}$ and ${ }^{17} \Delta$ measurements under bloom conditions during May 2008 in the subpolar N. Atlantic is more than double the ratio estimated previously from $\mathrm{O}_{2} / \mathrm{Ar}$ and ${ }^{17} \Delta$ measurements in the subtropical, equatorial, southern and coastal ocean. However, over the annual cycle integrated to the winter MLD, a much lower NCP/GOP of $0.07 \pm 0.06$ is estimated that is similar to values measured in other regions of the ocean.

[65] Acknowledgments. We thank the captain and crew of the R/V Atlantic Companion for their support in obtaining seawater samples using their ship. Special thanks to Mark Haught for helping with the oxygen isotope and $\mathrm{O}_{2} /$ Ar measurements, Arne Körtzinger for encouraging this collaboration, and Jan Kaiser for helping with sampling during the Knorr cruise in May 2008. In particular, we want to acknowledge the financial support by NSF Ocean Sciences under grants OCE 0726510 (P.D.Q.), OCE 0628107 (M.J. Perry) and OCE 0628379 (E. D'Asaro and C. Lee). The sample collection onboard the Atlantic Companion was supported by the European Commission under the CARBOOCEAN project GOCE 511176-2 (Arne Körtzinger).

\section{References}

Alkire, M. B., et al. (2012), Estimates of net community production and export using high-resolution Lagrangian measurements of $\mathrm{O}_{2}, \mathrm{NO}_{3}$ and POC through the evolution of a spring diatom bloom in the North Atlantic, Deep Sea Res., Part I, in press.

Barkan, E., and B. Luz (2003), High precision measurements of ${ }^{17} \mathrm{O} /{ }^{16} \mathrm{O}$ and ${ }^{18} \mathrm{O} /{ }^{16} \mathrm{O}$ of $\mathrm{O}_{2}$ and $\mathrm{O}_{2} / \mathrm{Ar}$ ratio in air, Rapid Comm. Mass Spectrom., 17, 2809-2814, doi:10.1002/rcm.1267.

Behrenfeld, M. J., and P. G. Falkowski (1997), Photosynthetic rates derived from satellite-based chlorophyll concentration, Limnol. Oceanogr., 42, 1-20, doi:10.4319/lo.1997.42.1.0001.

Bender, M., et al. (1987), A comparison of four methods for determining planktonic community production, Limnol. Oceanogr., 32, 1085-1098, doi:10.4319/lo.1987.32.5.1085.

Bender, M., H. Ducklow, J. Kiddon, J. Marra, and J. Martin (1992), The carbon balance during the 1989 spring bloom in the N. Atlantic Ocean, Deep Sea Res., Part A, 39, 1707-1725, doi:10.1016/0198-0149(92) 90025-O.

Bender, M., J. Orchardo, M. Dickson, R. Barber, and S. Lindley (1999), In vitro $\mathrm{O}_{2}$ fluxes compared with ${ }^{14} \mathrm{C}$ production and other rate terms during the JGOFS Equatorial Pacific experiment, Deep Sea Res., Part I, 46, 637-654, doi:10.1016/S0967-0637(98)00080-6.
Briggs, N., M. J. Perry, I. Cetinic, C. Lee, E. D’Asaro, A. M. Gray, and E. Rehm (2011), High-resolution observations of aggregate flux during a sub-polar North Atlantic spring bloom, Deep Sea Res., Part I, 58, 1031-1039, doi:10.1016/j.dsr.2011.07.007.

Buesseler, K. O., M. P. Bacon, J. K. Cochran, and H. D. Livingston (1992), Carbon and nitrogen export during JGOFS North Atlantic Bloom Experiment estimated from ${ }^{234} \mathrm{Th}:{ }^{238} \mathrm{U}$ disequilibria, Deep Sea Res., Part A, 39, 1115-1137, doi:10.1016/0198-0149(92)90060-7.

Bury, S. J., P. W. Boyd, T. Preston, G. Savidge, and N. J. P. Owens (2001), Size-fractionated primary production and nitrogen uptake during a N. Atlantic phytoplankton bloom: Implications for carbon export estimates, Deep Sea Res., Part 1, 48, 689-720, doi:10.1016/S0967-0637(00) 00066-2.

Campbell, J., et al. (2002), Comparison of algorithms for estimating ocean primary production from surface chlorophyll temperature and irradiance, Global Biogeochem. Cycles, 16(3), 1035, doi:10.1029/2001GB001444.

Cermeno, P., S. Dutkiewicz, R. P. Harris, M. Follows, O. Schofield, and P. G. Falkowski (2008), The role of nutricline depth in regulating the ocean carbon cycle, Proc. Natl. Acad. Sci. U. S. A., 105, 20,344-20,349, doi:10.1073/pnas.0811302106.

Chipman, D. W., J. Marra, and T. Takahashi (1993), Primary production at $47^{\circ} \mathrm{N}$ and $20^{\circ} \mathrm{W}$ in the North Atlantic ocean: A comparison between the ${ }^{14} \mathrm{C}$ incubation method and the mixed layer carbon budget, Deep Sea Res., Part II, 40, 151-169, doi:10.1016/0967-0645(93)90011-B.

Emerson, S., P. Quay, D. Karl, C. Winn, L. Tupas, and M. Landry (1997), Experimental determination of the organic carbon flux from open-ocean surface waters, Nature, 389, 951-954, doi:10.1038/40111.

Emerson, S., C. Stump, and D. Nicholson (2008), Net biological oxygen production in the ocean: Remote, in-situ measurements of $\mathrm{O}_{2}$ and $\mathrm{N}_{2}$ in surface waters, Global Biogeochem. Cycles, 22, GB3023, doi:10.1029/ 2007 GB003095.

Fernandez, C., P. Raimbault, N. Garcia, and P. Rimmelin (2005), An estimation of annual new production and carbon fluxes in the northeast Atlantic Ocean during 2001, J. Geophys. Res., 110, C07S13, doi:10.1029/ 2004JC002616.

Gruber, N., C. D. Keeling, and N. R. Bates (2002), Interannual variability in the North Atlantic Ocean carbon sink, Science, 298, 2374-2378, doi:10.1126/science. 1077077 .

Hamme, R. C., and S. R. Emerson (2006), Constraining bubble dynamics and mixing with dissolved gases: Implications for productivity measurements by oxygen mass balance, J. Mar. Res., 64, 73-95, doi:10.1357/ 002224006776412322 .

Helman, Y., E. Barkan, D. Eisenstadt, B. Luz, and A. Kaplan (2005), Fractionation of the three stable oxygen isotopes by oxygen producing and oxygen consuming reactions in photosynthetic organisms, Plant Physiol., 138, 2292-2298, doi:10.1104/pp.105.063768.

Hendricks, M. B., M. L. Bender, and B. A. Barnett (2004), Net and gross $\mathrm{O}_{2}$ production in the southern ocean from measurements of biological $\mathrm{O}_{2}$ saturation and its triple isotope composition, Deep Sea Res., Part I, 51, 1541-1561.

Hendricks, M. B., M. L. Bender, B. A. Barnett, P. Strutton, and F. P. Chavez (2005), Triple oxygen isotope composition of dissolved oxygen in the equatorial Pacific: A tracer of mixing, production and respiration, J. Geophys. Res., 110, C12021, doi:10.1029/2004JC002735.

Henson, S. A., J. P. Dunne, and J. L. Sarmiento (2009), Decadal variability in North Atlantic phytoplankton blooms, J. Geophys. Res., 114, C04013, doi:10.1029/2008JC005139.

Jenkins, W. J., and S. C. Doney (2003), The subtropical nutrient spiral, Global Biogeochem. Cycles, 17(4), 1110, doi:10.1029/2003GB002085.

Joint, I., A. Pomroy, G. Savidge, and P. Boyd (1993), Size-fractionated primary productivity in the northeast Atlantic in May-July 1989, Deep Sea Res., Part II, 40, 423-440, doi:10.1016/0967-0645(93)90025-I.

Juranek, L. W., and P. D. Quay (2010), Basin-wide photosynthetic production rates in the subtropical and tropical Pacific Ocean determined from dissolved oxygen isotope ratio measurements, Global Biogeochem. Cycles, 24, GB2006, doi:10.1029/2009GB003492.

Juranek, L. W., R. C. Hamme, J. Kaiser, R. Wanninkhof, and P. D. Quay (2010), Evidence of $\mathrm{O}_{2}$ consumption in underway seawater lines: Implications for air-sea $\mathrm{O}_{2}$ and $\mathrm{CO}_{2}$ fluxes, Geophys. Res. Lett., 37, L01601, doi:10.1029/2009GL040423.

Kaiser, J. (2011), Technical note: Consistent calculation of aquatic gross production from oxygen triple isotope measurements, Biogeosciences, 8, 1793-1811, doi:10.5194/bg-8-1793-2011.

Kolber, Z. S., O. Prazil, and P. G. Falkowski (1998), Measurements of the variable chlorophyll fluorescence using fast repetition rate techniques: Defining methodology and experimental protocols, Biochim. Biophys. Acta, 1367, 88-106, doi:10.1016/S0005-2728(98)00135-2. 
Körtzinger, A., et al. (2008), The seasonal $\mathrm{pCO}_{2}$ cycle at $49^{\circ} \mathrm{N} / 16.5^{\circ} \mathrm{W}$ in the northeastern Atlantic Ocean and what it tells us about biological productivity, J. Geophys. Res., 113, C04020, doi:10.1029/2007JC004347.

Laws, E. A., M. R. Landry, R. T. Barber, L. Campbell, M. L. Dickson, and J. Marra (2000), Carbon cycling in primary production bottle incubations: Inferences from grazing experiments and photosynthetic studies using ${ }^{14} \mathrm{C}$ and ${ }^{18} \mathrm{O}$ in the Arabian Sea, Deep Sea Res., Part II, 47, 1339-1352, doi:10.1016/S0967-0645(99)00146-0.

Liss, P. S., and L. Merlivat (1986), Air-sea exchange rates: Introduction and synthesis, in The Role of Air-Sea Exchange in Geochemical Cycling, edited by P. Buat-Ménard, pp. 113-127, D. Reidel, Dordrecht, Netherlands.

Liu, W. T. (2002), Progress in scatterometer application, J. Oceanogr., 58, 121-136, doi:10.1023/A:1015832919110.

Lochte, K., H. W. Ducklow, M. J. R. Fasham, and C. Stienen (1993), Plankton succession and carbon cycling at $47^{\circ} \mathrm{N} 20^{\circ} \mathrm{W}$ during the JGOFS North Atlantic Bloom Experiment, Deep Sea Res., Part II, 40, 91-114, doi:10.1016/0967-0645(93)90008-B.

Luz, B., and E. Barkan (2000), Assessment of oceanic productivity with the triple-isotope composition of dissolved oxygen, Science, 288, 2028-2031, doi: $10.1126 /$ science.288.5473.2028.

Luz, B., and E. Barkan (2005), The isotopic ratios ${ }^{17} \mathrm{O} /{ }^{16} \mathrm{O}$ and ${ }^{17} \mathrm{O} /{ }^{16} \mathrm{O}$ in molecular oxygen and their significance in biogeochemistry, Geochim. Cosmochim. Acta, 69, 1099-1110, doi:10.1016/j.gca.2004.09.001.

Luz, B., and E. Barkan (2009), Net and gross oxygen production from $\mathrm{O}_{2}$ $\mathrm{Ar},{ }^{17} \mathrm{O} /{ }^{16} \mathrm{O}$ and ${ }^{18} \mathrm{O} /{ }^{16} \mathrm{O}$ ratios, Aquat. Microb. Ecol., 56, 133-145, doi: $10.3354 /$ ame01296.

Luz, B., and E. Barkan (2011), Proper estimation of marine gross $\mathrm{O}_{2}$ production with ${ }^{17} \mathrm{O} /{ }^{16} \mathrm{O}$ and ${ }^{18} \mathrm{O} /{ }^{16} \mathrm{O}$ ratios of dissolved $\mathrm{O}_{2}$, Geophys. Res. Lett., 38, L19606, doi:10.1029/2011GL049138.

Marra, J. (2002), Approaches to the measurement of plankton production, in Phytoplankton Productivity and Carbon Assimilation in Marine and Freshwater Ecoystems, edited by P. J. Williams, D. R. Thomas, and C. S. Reynolds, pp. 222-264, Blackwell, London.

Marra, J. (2009), Net and gross productivity: Weighing in with ${ }^{14} \mathrm{C}$, Aquat. Microb. Ecol., 56, 123-131, doi:10.3354/ame01306.

Martin, J. H., S. E. Fitzwater, R. M. Gordon, C. N. Hunter, and S. J. Tanner (1993), Iron, primary production and carbon-nitrogen flux studies during the JGOFS N. Atlantic bloom experiment, Deep Sea Res., Part II, 40, 115-134, doi:10.1016/0967-0645(93)90009-C.

Martin, P., R. S. Lampitt, M. J. Perry, R. Sanders, C. Lee, and E. D’Asaro (2011), Export and mesopelagic particle flux during a North Atlantic spring diatom bloom, Deep Sea Res., Part I, 58, 338-349, doi:10.1016/ j.dsr.2011.01.006.

Moore, J. K., S. C. Doney, J. A. Kleypas, D. M. Glover, and I. Y. Fung (2001), An intermediate complexity marine ecosystem model for the global domain, Deep Sea Res., Part II, 49, 403-462, doi:10.1016/ S0967-0645(01)00108-4.

Nicholson, D. P. (2011), Comment on "Consistent calculation of aquatic gross production from oxygen triple isotope measurements" by Kaiser (2011), Biogeosci. Discuss., 8, 7127-7139, doi:10.5194/bgd-8-7127-2011.

Nightingale, P. D., G. Malin, C. S. Law, A. J. Watson, P. S. Liss, M. I. Liddicoat, J. Boutin, and R. C. Upstill-Goddard (2000), In situ evaluation of air-sea gas exchange parameterizations using novel conservative and volatile tracers, Global Biogeochem. Cycles, 14, 373-387, doi:10.1029/ 1999GB900091.

Oschlies, A., and P. Kahler (2004), Biotic contribution to air-sea fluxes of $\mathrm{CO}_{2}$ and $\mathrm{O}_{2}$ and its relation to new production, export production, and net community production, Global Biogeochem. Cycles, 18, GB1015, doi:10.1029/2003GB002094.

Peterson, B. J. (1980), Aquatic primary productivity and the ${ }^{14} \mathrm{C}_{-}-\mathrm{CO}_{2}$ method: A history of the primary production problem, Annu. Rev. Ecol. Syst., 11, 359-385, doi:10.1146/annurev.es.11.110180.002043.
Prokopenko, M. G., O. M. Pauluis, J. Granger, and L. Y. Yeung (2011), Exact evaluation of gross photosynthetic production from the oxygen triple-isotope composition of $\mathrm{O}_{2}$ : Implications for the net-to-gross primary production ratios, Geophys. Res. Lett., 38, L14603, doi:10.1029/ 2011GL047652.

Quay, P. D., C. Peacock, K. Björkman, and D. M. Karl (2010), Measuring primary production rates in the ocean: Enigmatic results between incubation and non-incubation methods at Station ALOHA, Global Biogeochem. Cycles, 24, GB3014, doi:10.1029/2009GB003665.

Reuer, M. K., B. A. Barnett, M. L. Bender, P. G. Falkowski, and M. B. Hendricks (2007), New estimates of southern ocean biological production rates from $\mathrm{O}_{2} / \mathrm{Ar}$ ratios and triple isotope composition of $\mathrm{O}_{2}$, Deep Sea Res., Part I, 54, 951-974, doi:10.1016/j.dsr.2007.02.007.

Robertson, J. E., A. J. Watson, C. Langdon, R. D. Ling, and J. W. Wood (1993), Diurnal variations in surface $\mathrm{pCO}_{2}$ and $\mathrm{O}_{2}$ at $60^{\circ} \mathrm{N} 20^{\circ} \mathrm{W}$ in the N. Atlantic, Deep Sea Res., Part II, 40, 409-422, doi:10.1016/09670645(93)90024-H.

Sabine, C. L., et al. (2004), The oceanic sink for anthropogenic $\mathrm{CO}_{2}, \mathrm{Sci}$ ence, 305, 367-371, doi:10.1126/science.1097403.

Sambrotto, R. N., G. Savidge, C. Robinson, P. Boyd, T. Takahashi, D. M. Karl, C. Langdon, D. Chipman, J. Marra, and L. Codispoti (1993), Elevated consumption of carbon relative to nitrogen in the surface ocean, Nature, 363, 248-250, doi:10.1038/363248a0.

Siegel, D. A., S. C. Doney, and J. A. Yoder (2002), The North Atlantic spring phytoplankton bloom and Sverdrup's critical depth hypothesis, Science, 296, 730-733, doi:10.1126/science.1069174.

Stanley, R. H. R., J. B. Kirkpatrick, N. Cassar, B. A. Barnett, and M. L. Bender (2010), Net community production and gross primary production rates in the western equatorial Pacific, Global Biogeochem. Cycles, 24, GB4001, doi:10.1029/2009GB003651.

Steinhoff, T., T. Friedrich, S. E. Hartman, A. Oschlies, D. W. R. Wallace, and A. Körtzinger (2010), Estimating mixed layer nitrate in the North Atlantic Ocean, Biogeosciences, 7, 795-807, doi:10.5194/bg-7-7952010

Stendardo, I., N. Gruber, and A. Körtzinger (2009), CARINA oxygen data in the Atlantic Ocean, Earth Syst. Sci. Data, 1, 87-100, doi:10.5194/essd1-87-2009.

Sverdrup, H. U. (1953), On conditions for the vernal blooming of phytoplankton, ICES J. Mar. Sci., 18, 287-295, doi:10.1093/icesjms/18.3.287.

Takahashi, T., et al. (2009), Climatological mean and decadal change in surface ocean $\mathrm{pCO}_{2}$ and net sea-air $\mathrm{CO}_{2}$ flux over the global oceans, Deep Sea Res., Part II, 56, 554-577, doi:10.1016/j.dsr2.2008.12.009.

Wanninkhof, R. (1992), Relationship between wind speed and gas exchange over the ocean, J. Geophys. Res., 97, 7373-7382, doi:10.1029/92JC00188.

Wentz, F. J., D. K. Smith, C. A. Mears, and C. L. Gentemann (2001), Advanced algorithms for QuikScat and SeaWinds/AMSR, Proc. IEEE, 3, 1079-1081, doi:10.1109/IGARSS.2001.976752.

Westberry, T., M. J. Behrenfeld, D. A. Siegel, and E. Boss (2008), Carbonbased primary productivity modeling with vertically resolved photoacclimation, Global Biogeochem. Cycles, 22, GB2024, doi:10.1029/ $2007 \mathrm{~GB} 003078$.

Williams, P. J. le B., P. J. Morris, and D. M. Karl (2004), Net community production and metabolic balance at the oligotrophic ocean site: Station ALOHA, Deep Sea Res., Part I, 51, 1563-1578.

P. Quay and J. Stutsman, School of Oceanography, University of Washington, PO Box 355351, Seattle, WA 98195, USA. (pdquay@u. washington.edu)

T. Steinhoff, IFM-GEOMAR, Leibniz Institut für Meereswissenschafte, Kiel D-24105, Germany. 